Portland State University

PDXScholar

1976

\title{
The Proposed Community Involvement Activities of the Multnomah County Department of Public Safety: a Descriptive Study
}

Vertis Williams

Portland State University

Leearthur Madison

Portland State University

Follow this and additional works at: https://pdxscholar.library.pdx.edu/open_access_etds

Part of the Social Work Commons

Let us know how access to this document benefits you.

\section{Recommended Citation}

Williams, Vertis and Madison, Leearthur, "The Proposed Community Involvement Activities of the Multnomah County Department of Public Safety : a Descriptive Study" (1976). Dissertations and Theses. Paper 1863.

https://doi.org/10.15760/etd.1862

This Thesis is brought to you for free and open access. It has been accepted for inclusion in Dissertations and Theses by an authorized administrator of PDXScholar. Please contact us if we can make this document more accessible: pdxscholar@pdx.edu. 
THE PROPOSED COMINUNITY INVOLVENENT ACTIVITIES OF THE MULTNONAH COUNTY DEPARTIENT OF PUBLIC SAFETY:

A DESCRIPTIVE STUDY

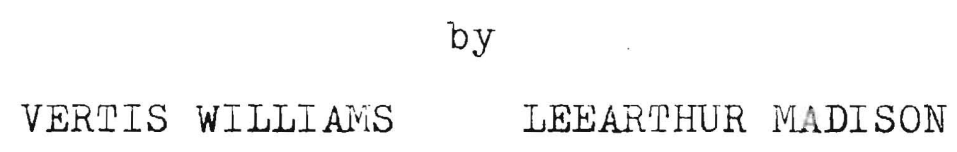

A practicum submitted in partial fulfillment of the requirements for the degree of

MASTER OF SOCIAL WORK

Portland State University

1976 
APPROVED:

Nancy Goroloff, Assedtant Professor of Research

May 21, 1976 


\section{ACKNOWLEDGNENTS}

We wish to express our gratitude first and foremost to our wives, Jacqueline Williams and Iris Madison, for their continual support and patience during our efforts to produce this document.

Sincere appreciation is expressed to Nancy Koroloff, our advisor, and to Lynn Thompson for their assistance and guidance.

Appreciation is also expressed to Sheriff Lee Brown and to vike Letter for allowing us to conduct this research at the Multnoman County Department of Public Safety.

A special thanks is deserved by Karen Stover for her excellent typing and tecinnical assistance. 
TABLE OF CONTENTS

PAGE

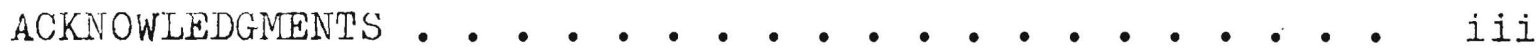

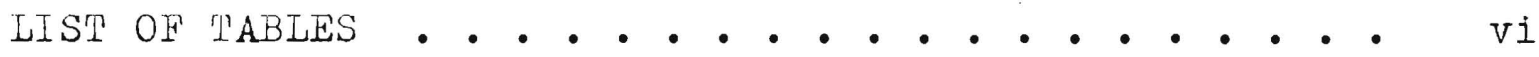

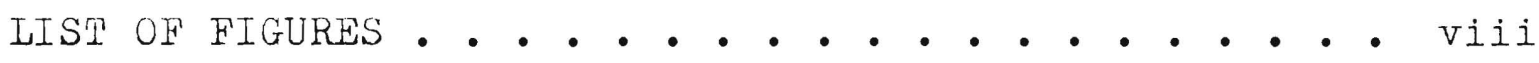

CHAPTER

I INTRODUCTION. . . . . . . . . . . 1

II THE CONCEPT OF NEIGHBORHOOD TEAM POLICING • • 5

Combining All Iine Operations of Patrol,

Traffic, and Investigation Into a

Single Group Under Common Supervision • 6

Forming Teams With a Mixture of Specialist and Generalist. . . . . . . . 9

Permanently Assigning the Teams to Geographic Areas and Charging the Teams with Responsibility for all Police

Services Within Their Respective Areas. 11

III REVIEW OF THE IITERATURE. • • . • • • . 15

IV RESEARCH DESIGN AND METHODOLOGY • • • • • 28

Population . . . . . . . . 29

Development of the Instrument. . . . 29

Administration of the Instrument . . . 31

Data Analysis. . . . . . . . 31

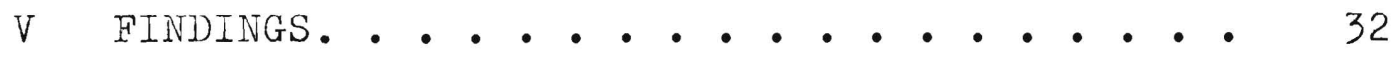

Public Information and Education . . . 32

Training . . . . . . . . . 39 


\section{IIST OF TABLES}

PABLE

PAGE

I Were Public Information Activities Conducted Prior to Implementation of Neighborhood Team Policing? . . .

II How Successful Respondents Felt the Administrative Process Was in Informing the Public About Neighborhood Team Policing . . . . . . . .

II Is Ihere a Written Public Education Plan? • . • . . . . . .

IV Is There a Written On-going Public Information Program? . . . . . .

V Prior to Neighborhood Tearn Policing, Was Training Provided Officers to Prepare Them to Become Generalist Police Officers? • . . . . . . . . .

VI Objectives of the Training Retreats . .

VII what Activities rook Place at the Retreats? . . • . . . . . . .

VII After Implementation of Neighborhood

leam Policing, Was Human Relations

Training Provided Officers? . . . . 
IX How Successful Respondents Felt the

$$
\begin{aligned}
& \text { Administrative Process Was in Pro- } \\
& \text { viding Officers With Human Relations } \\
& \text { Praining . . . . . . . . . . . }
\end{aligned}
$$

$x$ Is There a Written Community Change

$$
\text { Process Plan? • • • • • • . • }
$$

XI What Does a Community Service Officer

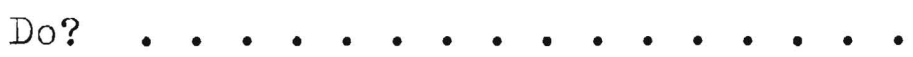

XII Has Each Team Developed a Profile of 


\section{IIST OF FIGURES}

FIGURE

PAGE

1 Police Functional Classification Chart . . .

2 Organizational Structure of the Nultnomah County Department of Public Safety . • . 
CHAPTER I

\section{INTRODUCTION}

According to the National Advisory Commission On Criminal Justice Standards and Goals, community support and cooperation with the police are deemed critical to crime prevention and the effective delivery of police services. ${ }^{1}$ One main reason for this is that measures of reported criminal incidents in cities across the country continue to increase. Police budget and manpower constraints limit police abilities to deal with this increase through their own efforts. Hence, the police must rely upon citizens to report crimes and provide them with information that will increase the probability that offenders will be apprehended. They must also rely upon citizens to actively participate in crime prevention and crime control programs.

Recognizing this fact, many law enforcement agencies have attempted to develop programs geared to promoting community involvement. One such attempt has been the implementation of a program referred to as Full Service Neighborhood Team Policing. Full Service Neighborhood Team Policing can be defined as: (1) combining all line operations of

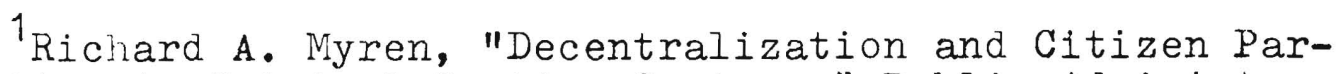
ticipation in Criminal Justice Systems," Public Administration Review, XXXII (October, 1972), p. 718 . 
patrol, traffic, and investigation into a single group under common supervision; (2) forming teams with a mixture of generalist and specialist; (3) permanently assigning the teams to geographic areas; and (4) charging the teams with responsibility for all police services within the respective areas. ${ }^{2}$ On July 1, 1975, the Multnomah County Department of Public Safety ${ }^{3}$ received a grant from the United States Department of Justice Law Enforcement Assistance Administration to implement Full Service Neighborhood Team Policing. In the Grant Application submitted to the Law Enforcement Assistance Administration, the Multnomah County Department of Public Safety stated that Neighborhood Team Policing is expected to achieve the following broadly stated goals:

1. Improved police-community mutual involvement and problem-solving.

2. Increased level of police service rendered the community.

3. Increased police effectiveness in controlling and reducing crime.

4. Improved job satisfaction for deputies. ${ }^{4}$

2 National Advisory Commission On Criminal Justice Standards and Goals, Police: Task Force Report (Washington, D.C.: Government Printing office, 1973), p. 156.

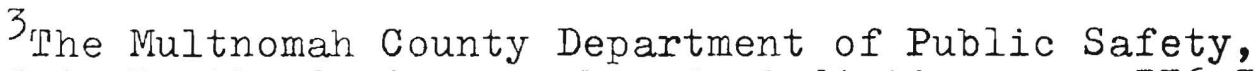
located in Portland, Oregon, has jurisdiction over 376.5 miles with a population of 180,000, excluding the city of Portland and the city of Gresham.

${ }^{4}$ Edgar E. Martin et al., "Multnomah County Department of Public Safety Neighborhood Team Policing Grant Proposal: Program Narrative," (Multnomah County, Oregon, 1975), pp. 17-18. 
In order to determine the degree of attainment of these goals, the development of an evaluation system was necessary. Being cognizant of this fact, the Multnomah County Department of Public Safety established an evaluation unit, responsible for development, implementation, and monitoring of evaluative systems. The evaluation unit developed a proposed evaluation design to assess the effectiveness of the Neighborhood Team Policing Project.

The proposed evaluation design stipulates that the evaluation of the Neighborhood Team Policing Project will consist of two areas of separate but highly interrelated activities. 5 These two areas of activities are: (1) the ongoing monitoring of project activities, and (2) the output measurement of project activities relative to project planning, project objectives, project coordination, project impact, institutional response, resource level, and resource allocation. 6

Serving in the capacity of Sheriff's interns during the time the decision had been made to implement Neighborhood Team Policing, the writers of this study propose to participate in evaluating the impact and effectiveness of the project. However, due to the size and complexity of such a task-and the time restrictions placed upon completion

${ }^{5}$ Multnomah County Department of Public Safety Proposed Neighborhood Team Policing Evaluation Design (Multnomah County, Oregon, 1976), p. 2 .

Ibid. 
of this study--the boundaries of this research will be Iimited to those of providing descriptive data on the performance of project activities ${ }^{7}$ as they relate to the achievement of the objectives of Goal 1 of the Neighborhood Team Policing Project: Improved police-community mutual involvement and problem-solving.

The community involvement aspect of the Neighborhood Team Policing Project was focused on because most law enforcement agencies that have implemented a Neighborhood Team Policing Program have focused upon the community as their constituency and have placed strong emphasis upon improving police-community relations and active citizen participation in crime prevention. With these ideas in mind, a variety of community involvement programs have been developed. Results of such programs have been mixed and have not been traceable to any particular activity. They have simply been reported as results of Neighborhood Team Policing Programs in general or as strategies implemented by the program. This research will attempt to provide descriptive data on the activities that can be traced to community involvement component of the Multnomah County Department of Public Safety's Neighborhood Team Policing Program.

7 The terms "activities" and "tasks" will be used interchangeably. 
CHAPTER II

THE CONCEPT OF NEIGHBORHOOD TEAM POLICING

The concept of "Team Policing" was given primary impetus in this country in 1967 when the President's Commission on Law Enforcement and Administration of Justice suggested that:

Police departments should commence experimentation with a team policing concept that envisions those with patrol and investigative duties combining under command with flexible assignments to deal with the crime problem in a defined sector. 8

The commission's report stressed command decentralization of authority down to field supervisory level and unification of patrol and criminal investigative functions. 9

Many law enforcement agencies have attempted to operationalize the suggestions advance by the commission. However, due to the lack of a single definition or model, team policing has been operationalized differently in every community where it has been found. What has resulted are programs consisting of a combination of various activities focused to achieve certain goals.

${ }^{8}$ President's Commission on Law Enforcement and Administration of Justice, The Challenge of Crime in a Free Society (Washington, D.C.: $\frac{\text { Government Printing }}{\text { Pre }}$ Office, 1967), p. 118.

9 Ibid. 
Although there is no single definition or model, there are certain elements incumbent in Neighborhood Team Policing as it is currently operationalized in a number of law enforcement agencies. These elements are: (1) combining all line operations of patrol, traffic and investigation into a single group under common supervision; (2) forming teams with a mixture of specialist and generalist; (3) permanently assigning the teams to geographic areas; and (4) charging the teams with responsibility for all police services within the respective areas. 10 Each of these elements are present in the Neighborhood Team Policing model conceptualized and practiced by the Multnomah County Department of Public Safety. These elements will now be considered in detail.

Combining All Line Operations of Patrol, Traffic, and Investigation Into a Single Group Under Common Supervision

The vast majority of law enforcement agencies are highly centralized; that is, "control" and decision-making is concentrated in a central power. More specifically, most law enforcement agencies possess all the characteristics inherent in bureaucracy--a hierarchy of authority, status, and formal position or ranks, a division of labor into highly specialized activities, functions, and units, and a system of rules and procedures for dealing with all work activities, established routines that are learned primarily

${ }^{10}$ National Advisory Commission On Criminal Justice Standards and Goals, op. cit., p. 156. 
through experiences in the organization and impersonality in handling both employees and clientele. ${ }^{11}$

Also, in the vast majority of law enforcement agencies, responsibilities are classified functionally; that is, police responsibilities are designated as line functions and staff functions. Line functions consist of general operations and specialized operations. Staff functions consist of administrative and support activities ${ }^{12}$ (see Figure 1).

Line functions are those basic operations which are performed to achieve the main objectives of the agency. They generally involve direct contact between police officers and members of the public. Staff functions are those basic activities which are required to keep line police officers operational. Staff functions involve minimal contact with the public.

The Neighborhood Team Policing model implies functional decentralization and de-emphasizes specialized operations. It envisions those officers previously specialized in patrol and investigative duties combined under a unified command with flexibility in assignment. This serves two purposes: it allows for participatory management, which is a method of improving services by utilizing the abilities, experience, and talents of all personnel levels by soliciting their inputs

${ }^{11}$ Police Consolidation Project, Staff Report, V (Portland, Oregon: Police Consolidation Project, 1974), p. 77. 12 Ibid., p. 75 . 


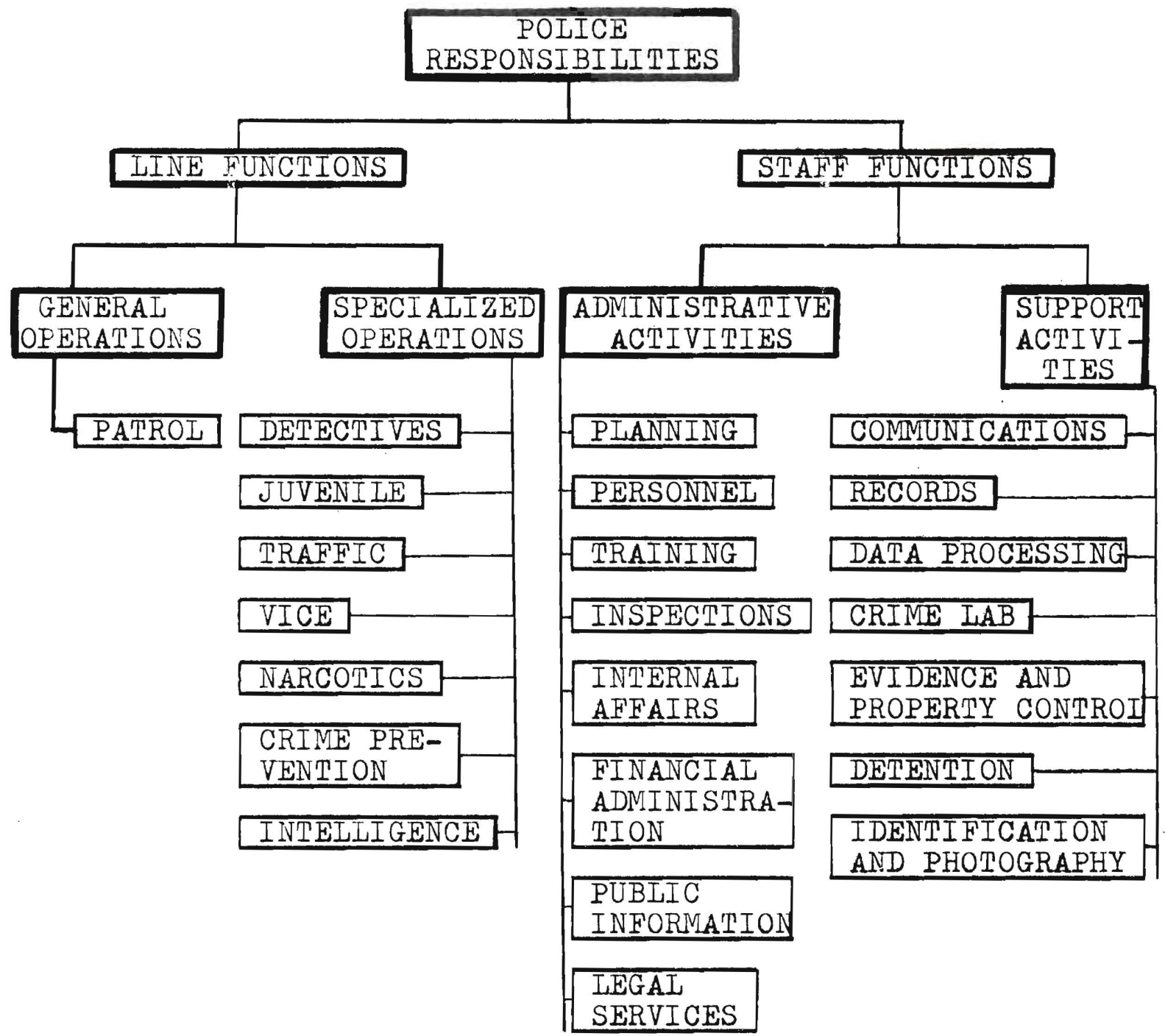

Figure 1. Police Functional Classification Chart.

and permitting decision-making at the lowest possible level $;^{13}$ and it enhances the two-way nature of the communication process.

In the Multnomah County Department of Public Safety, this element of Neighborhood Team Policing (combining all

${ }^{13}$ George B. Sandler and Ellen Mintz, "Police Organizations: Their Changing Internal and External Relationships," Journal of Police Science and Administration, II (December, 1974), $\mathrm{p} \cdot 4$ 62. 
line operations of patrol, traffic, and investigation into a single group under common supervision) is found in the department's decentralization of four line functions. These include patrol, traffic, youth services, and some detective functions.

Forming Teams with a Mixture of Specialist and Generalist

The second element of Neighborhood Team Policing consists of forming teams with a mixture of specialist and generalist. This has become an important element of most Neighborhood Team Policing Programs. Reasons for this are found in the distinction between the specialist and the generalist police officer.

The police specialist is a system under which various police tasks are assigned to officers who handle solely those tasks. 14 For example, under a specialist system, delivery of police services is reactive, with patrol officers responding to calls for citizen assistance. That is, when a crime is reported, the patrol officer proceeds immediately to the scene and conducts a preliminary investigation. After the preliminary investigation is completed, the case is immediately passed on to specialists in criminal investigations. After thorough investigation by a detective specialist, the case is finally turned over to a court

${ }^{14}$ G. Douglas Gourley et al., "Patrol Specialization vs. Generalization," Effective Police Organization and Management, IV (October, 1966) , p. 331. 
liaison officer (who is a specialist in dealing with the District Attorney and the courts) who will decide in some cases what charges will be sought against the suspect, and under which jurisdiction they will attempt to arraign him. The police generalist is a system under which the police officer executes every detail and segment of the total police job. ${ }^{15}$ He handles a case all the way from the preliminary investigation to court disposition. If a situation arises where the officer does not possess the needed knowledge to proceed with the investigation, he calls upon the members of his team that specializes, or have had experience, in the area of need.

Proponents of Neighborhood Team Policing ${ }^{16}$ argue that forming teams with a mixture of specialist and generalist will increase contact and communication between patrol officers and detectives (which would lead to a greater reduction in crime rate), prevent duplication of services, and enlarge the job role and responsibilities of the patrolman by providing an organizational context for him to perform more complicated tasks as his experience increases. In the Multnomah County Department of Public Safety, this element of Neighborhood Team Policing (forming teams with a mixture of specialist and generalist) is found in

${ }^{15}$ Ibid., p. 330 .

16 National Advisory Commission on Criminal Justice Standards and Goals, A Strategy to Reduce Crime (Washington, D.C.: Government Printing Office, 1973), pp. 77-78. 
the department's formation of five neighborhood teams and one support team. Each team consists of twenty to forty officers working under the supervision of a team manager. The support team is organizationally centralized and consists of specialized personnel. The purpose for this is that there are some very serious and complex cases that require prolonged and specialized investigation. The teams are responsible to the Division Commander (see Figure 2).

Permanently Assigning the Teams to Geographic Areas and Charging the Teams with Responsibility for all Police Services Within Their Respective Areas

The last two elements incumbent in most Neighborhood Team Policing Programs--and the ones which have more significant implications for this study--are permanently assigning the teams to geographic areas and charging the teams with responsibility for all police services within their respective areas. These two elements are combined because they are interrelated. The basic rationale is that stable assignment will strengthen and improve police-community relations; thus, citizen support and involvement--which are held critical to crime prevention and successful law enforcement--will be obtained. ${ }^{17}$ The rationale is also based on the fact that team members will be sent out of their team area only in emergencies. This allows for accountability to be

${ }^{17}$ National Sheriff's Association, Issues in Team Policing: A Review of the Literature (Washington, D.C.: U.S. Department of Justice, 1975), p. 36 . 


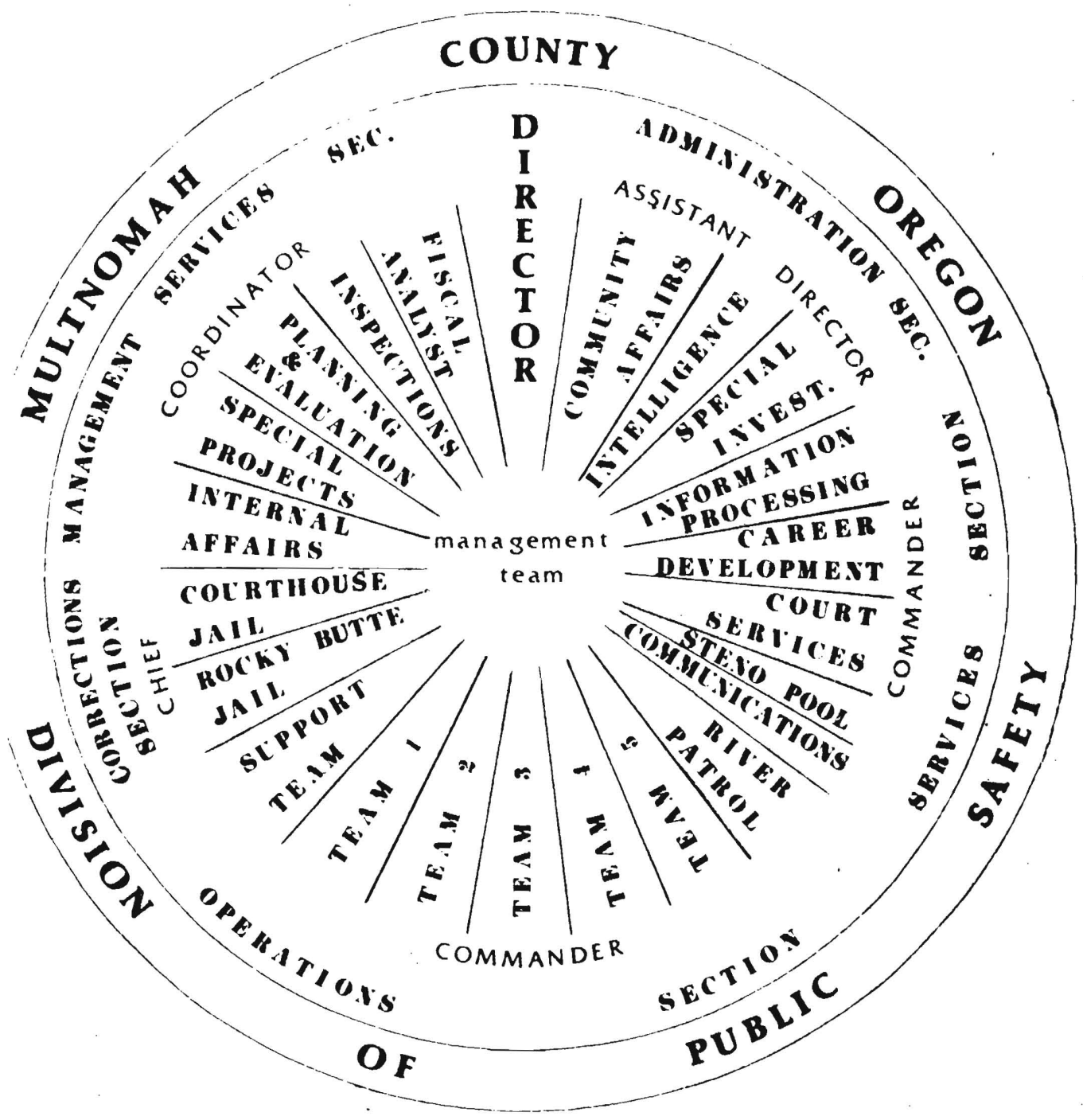

Figure 2. Organizational Structure of the Multnomah County Department of Public Safety. 
narrowly focused at the team level.

In the Niltnomah County Department of Public Safety, the neighborhood teams are accountable to the Operations Division Commander, who is responsible for the direction and coordination of the six functional teams. The Operations Division Commander is responsible to the Director of Public Safety.

Several methods have been used to determine the size of Neighborhood Team Policing areas and the level of manpower assigned to the area. Some programs have determined size of area on the basis of crime analysis and work load demand. ${ }^{18}$ other programs have identified pre-existing or "natural" neighborhoods that are geographically, politically, culturally, or ethnically distinct areas as team areas. 19

In the Multnomah County Department of Public Safety, permanently assigning the teams to geographic areas was done by considering the approximate population by census tract, police work load, juvenile delinquency, general examination of economic and social factors, city limits, school districts, and natural boundaries. 20

The options--and the extent to which they are emphasized--related to the last two elements of Neighborhood Team Policing are many and varied. However, they include

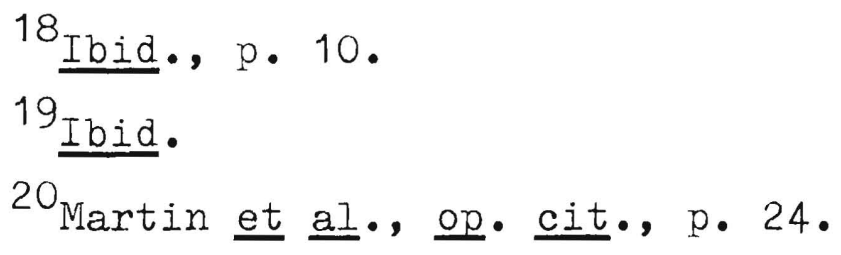


such things as storefront headquarters, referral services, community service officer programs, crime prevention programs, citizen advisory councils, work and talk programs, citizen volunteer programs, etc. 
CHAPTER III

REVIEW OF THE IITERATURE

The vast majority of the literature written on Neighborhood Team Policing has been supportive. It focuses on the elements common to most Neighborhood Team Policing Programs and the activities or strategies generally undertaken to operationalize them. These elements and activities fall basically into two categories--those that impact or directly relate to the organization and those that impact or directly relate to the community. Since this study is only a portion of the total evaluation of Neighborhood Team Policing as implemented by the Multnoman County Department of Public Safety, and since its focus is only upon community involvement as an aspect of the Neighborhood Team Policing Program, most of the literature review will be directed toward studies done in this area.

Because Neighborhood Team Policing suggests a radical change in the basic structure of traditional organizations, many proponents of it start out by criticizing classic bureaucracies in general and police organizations in particular. These criticisms are attempts to show how the organization of traditional police agencies create problems that impact the agencies ability to effectively deliver 
police services, and consequently impact the community. Proponents conclude by suggesting Neighborhood Team Policing as an alternative to traditional policing.

Perhaps one of the better articles in which this criticism and comparison is found is in the one provided by Angell (1971).21 Angell discusses how the structure of modern American police organizations reflect the influence of classic organizational theory. He points out four criticisms of classic organizational theory. They are:

1. Classic theory and concepts are culture bound.

2. Classic theory and concepts mandate that attitudes toward employees and clients be inconsistent with the humanistic democratic values of the United States.

3. Classic structured organizations demand and support employees who demonstrate immature personality traits.

4. Classic organizations are unable to cope with environmental changes; therefore, they eventually become obsolete and dysfunctional.22

Many problems are related to the four mentioned criticisms of classic organizational theory. But, the most significant and appropriate one is that classic organizational theory perpetuates negative police-community relations. 23 One main reason for this is that role relationships and

21 John E. Angell, "Toward An Alternative to the Classic Police Organizational Arrangements: A Democratic Model," Criminology, IX (August-November, 1971), p. 185.

\footnotetext{
${ }^{22}$ Ibid., pp. 187-188.

23 Ibid., p. 190.
} 
processes within organizations that adhere to the principles of classic organizational theory establish a model for interaction with the public. In terms of police image, the model is usually military and, therefore, carries a connotation of war and conflict. Hence, for an example, police are often viewed by ghetto communities as an occupying army.

Angell offers Neighborhood Team Policing as an alternative to the classic organizational structure. He states that:

The model is an attempt to develop a flexible participatory science-based structure that will accommodate change. It is designed for effectiveness in serving the needs of the citizens rather than autocratic rationality of operation. It is democratic in that it requires and facilitates the involvement of citizens and employees in its processes. It is designed to improve decision-making and role consensus among citizens and employees by increasing the exchanges of information and influence among the people who are related to the organization. 24

Aligned with the Angell article is the one written by Sandler and Mintz (1974). ${ }^{25}$ They too criticize the paramilitary organizational style that characterizes many law enforcement agencies. Their criticism centers around the idea that a para-military organizational structure tends to create a sense of demoralization and powerlessness at the lower ranks. 26 This tends to facilitate one-way communication which creates a perception of the top command as being

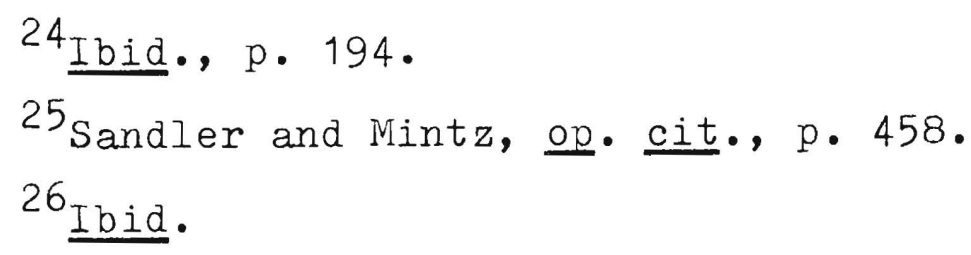


arbitrary in its actions. Not having had input into top management decisions and being deprived of access to their rationales results in feelings of cynicism among midde management as well as rank and file. ${ }^{27}$ This cynicism is aggravated because of the feeling that top command decisions are perceived as unrealistic by the time they reach the level of execution. 28 The end result is the reinforcement of a "we-they" feeling which creates a gap between the administrative and operational levels of the organization. The creation of such a gap encourages conflict rather than cooperative relationships.

The price paid for this state of affairs is rigidity in the organization as expressed through various blockages to change. Not having participated in the development of department programs, lower ranking members have no part in their success. Thus, programs are often ignored when they reach the level of execution. Not having received communication from that level, top management is often not aware that programs and policies have been implemented only on paper.

Sandler and Mintz conclude in their article that these in-house frustrations determine to a great extent the style in which the organization interacts with the community. ${ }^{29}$

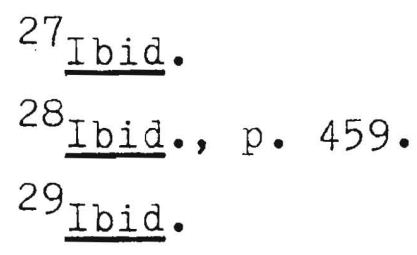


In fact, many of the frustrations felt by rank and file

officers will be expressed in one-to-one police-citizen interactions. This style often engenders, within citizens, feelings of anger, dissatisfaction, and alienation. The result is a lack of cooperation and withholding of information potentially relevant for crime prevention or investigation.

Koverman (1974) 30 suggests Neighborhood Team Policing as an alternative to the traditional style of policing. He points out that Neighborhood Team Policing accomplishes three objectives:

1. It develops a generalist-specialist, who is a police officer sufficiently skilled to be able to conduct all types of investigations from original dispatch to final disposition by the courts.

2. It produces a community centered police structure that is responsive to neighborhood life styles.

3. It alters the bureaucratic structure away from the para-military model toward the neighborhoodoriented generalist-specialist. 31

These objectives pointed out by Koverman are the most salient features of Neighborhood Team Policing. This is because they allow the organization to detect, respond, and adapt to change. But, why is it so essential, or even mandatory, that organizations--in particular law enforcement

30 Robert B. Koverman, "Team Policing: An Alternative to Traditional Law Enforcement Techniques," Journal of Police Science and Administration, II (March, 1974), p. 15.

${ }^{31}$ Ibid., pp. 15-16. 
agencies--be able to do this?

The answer lies in the fact that there is a tremendous diversity in our American society and a trend toward rapid change. This diversity in American society and trend toward rapid change has resulted in new demands being placed upon police agencies. For an example, during the 1960's police were faced with the problems of civil rights disturbances and ghetto riots. Today, a large number of police-citizen encounters are domestic in nature. A number of studies support these suggestions.

Sandler and Mintz $(1974)^{32}$ reported that 80-90 percent of police work is not directly related to law enforcement; rather, it consists of helping services and order maintenance. Police represent the first line of government when dealing with personal-emotional crisis of individual citizens. Epstein (1962) 33 reported similar conclusions. He estimated that 90 percent of the policeman's function is in activities unrelated to crime control or law enforcement. Cummings et al. $(1965)^{34}$ reported that one-half of all calls for assistance to an urban police department involve noncriminal or service matters or family crisis or other

${ }^{32}$ Sandler and Mintz, op. cit., p. 460.

${ }^{33}$ Charlott Epstein, Intergroup Relations for Police Officers (Baltimore, Maryland: Williams and Wilkins Company, 1962), p. 126.

34Elaine Cumming et al., "Policeman as Philosopher, Guide, and Friend," Social Problems, XII (W'inter, 1965), p. 285 . 
complaints of a personal or interpersonal nature. Germann $(1969)^{35}$ reported that the police officer spends about 90 percent of his time in public service activities and only about 10 percent, or less, of his time in "crook catching" activities. Webster $(1968)^{36}$ indicated that crimes against property and persons accounted for only 16 percent of policecitizen contacts. Black (1968) 37 reported that even in high crime areas, it appears that less than one-third of policecitizen encounters revolve around criminal incidents; noncriminal disputes and juvenile problems together account for 30 percent of the encounters observed. Ephross and French $(1972)^{38}$ indicated that husband-wife disputes ("domestics") constitute a sizable portion of all non-criminal cases.

The point of all of this is that police can no more view themselves as meriting "combat pay" or as a "thin blue line" separating the lawful from the lawless (Alex, 1969).39

35 A. C. Germann, "Community Policing: An Assessment," The Journal of Criminal Law, Criminology, and Police Science, IX $(\overline{\text { Narch, }} 1 \overline{969}), \mathrm{p} \cdot 94$.

$36 \mathrm{~J}$. A. Webster, "Police Task and Time Study," The Journal of Criminal Law, Criminology, and Police Science, II (March, 1970), p. 95.

37 D. J. Black, "Police Encounters and Soclal Organization: An Observation Study," (Ph.D. Dissertation, Department of Sociology, University of Michigan, 1968), p. 27.

38 P. H. Ephross and P. French, "Social Service and the Police," Hospital and Community Psychiatry, XXIII (January, 1972), p. 61.

${ }^{39}$ Nicholas Alex, Black in Blue: A Study of the Negro Policeman (New York: Harper and Row Publishers, 1967), p. 98. 
Instead, many of the situations which they face require them to take a humanistic service approach to their jobs (Whitehouse, 1973).40 (For an example, there is no way sophisticated law enforcement equipment can aid in the handing of a family dispute. The officer has to depend solely on his own human relations and problem-solving skills.)

Recognizing this fact, a number of law enforcement agencies (e.g. New York, Houston, Cincinnati, Dayton, Richmond, Missouri, Covina) have developed a variety of special programs in an attempt to bridge the gap between the police and the community and to provide officers with training in human relations.

One of these programs was developed in New York City by Morton Bard $(1968)^{41}$ (Bard and Berkowitz, 1967).42 Basically, the project was set up to demonstrate the possibilities for prevention of crime and promotion of mental health in training police as specialists in family crisis intervention.

There also have been several applications of T-group

40 Jack E. Whitehouse, "Historical Perspectives on the Police Community Service Function," Journal of Police Science and Administration, I (March, 1973), p. 87.

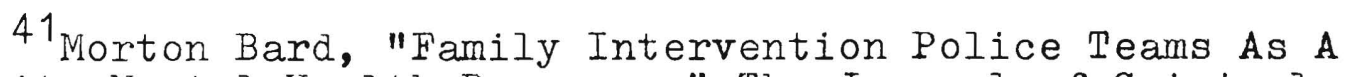
Community Mental Health Resource," The Jourmal of Criminal Law, Criminology, and Police Science, LX (June, 1969), p. 247.

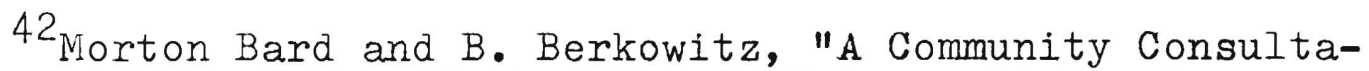
tion Program in Police Family Crisis Intervention: Preliminary Impressions," International Journal of Social Psychiatry, XV (Summer, 1969), p. 209 . 
sensitivity training in law enforcement agency training programs. Bell et al. $(1969)^{43}$ describes the use of these techniques in training officers of the Houston, Texas Police Department. The program consisted of small group discussions between police officers and community members, especially minority group representatives. The major goals of the program were to promote a cooperative relationship between the community and the police and to effect greater mutual respect and harmony. Participants in the program were cautiously affirmative in proclaiming the program a success.

In another study involving small group training techniques Mills $(1969)^{44}$ experimented with Cincinnati, Ohio police recruits in improving their attitudes toward social problems it was anticipated they would encounter as they go out into the community. He engaged the recruits in small group training and lectures.

A program (Borocas and Katz, 1970) 45 to train Dayton police in crisis intervention has been tried, in which the

${ }^{43}$ Robert I. Bell et al., "Small Group Dialogue and Discussion: An Approach to POlice Community Relationships," The Journal of Criminal Law, Criminology, and Police Science, LX $($ June, 1969), p. 242

${ }^{44}$ Robert B. Mills, "Use of Diagnostic Small Groups in Police Recruit Selection and Training," The Journal of Criminal Law, Criminology, and Police Science, IX (June, 1969), p. 238 .

45 Harvey Borocas and Myron I. Katz, "Dayton's Pilot Training Program: Crisis Intervention," Police Chief, XXXVIII (July, 1971), p. 20 . 
primary technique used was role-playing. The training was conducted by a group of psychologists and provided intensive training in dealing with youth, family, and community conflicts. Laboratory demonstrations consisted of dramatized conflicts role-played by professional actors with improvised police interventions (by trainees). Role-playing police interventions were videotaped and used subsequently as feedback.

Another instance of role-playing in police training is described by Phelps et al. (1971). ${ }^{46}$ Again, the subject matter for training was domestic crisis interventions. The training involved the Richmond Police Department and emphasized teaching concrete, learnable skills which can be employed in real-life situations. Simulated crisis intervention by trainees in dramatized situations was followed by a critical evaluation by fellow officers and the employment of videotape to enhance self-study and provide immediate feedback.

Another special kind of role-playing in training police is being carried on at the Regional Center for Criminal Justice in Missouri (Badalaments, et al., 1973).47

46 Lourn G. Phelps et al., "Training an Entire Patrol Division in Domestic Crisis Intervention Techniques," Police Chief, XXXVIII (July, 1971), p. 18.

47 Richard V. Badalaments et al., "Training Police For Their Social Role," Joumal of Police Science and Administration, I (December, 1973), p. 440. 
The training, which takes place at the center's "Response Stage," offers the trainee an opportunity to see for himself what his own capabilities are in stress situations. The Response Stage consists of a two-story building with an apartment complex on the second floor and a drug store and cleaning shop on the first. Within this complex, trainees are exposed to various types of situations and crime scenes "normally encountered in the field." Roles such as enraged apartment manager, disturbed runaway, and so on, are played by experienced officers from surrounding agencies. Trainees are then sent to face and deal with these situations, with instructors closely observing their reactions.

Another program (Johnson and Gregory, 1971), ${ }^{48}$ and supposedly one of the most successful, was the one conducted in Covina, California. An eight week course was designed to provide greater knowledge of values and ethics, individual human behavior, interpersonal and group relations, organizational behavior, intergroup or race relations, and the nature of the community for the twenty members of the Covina Police Department who participated. Included in the program was an opening two-day retreat, a series of seven discussion sessions, a field experience in Riverside County Jail, research and evaluation, and a closing banquet.

${ }^{48}$ Deborah Johnson and Robert J. Gregory, "PoliceCommunity Relations in the United States: A Review of the Literature and Projects," The Journal of Criminal Law, Criminology, and Police Science, IXII (June, 1971). 
Finally, elements of Neighborhood Team Policing have been aimed at improving police-community relations. The most important of these has been permanent assignment of officers to geographic areas.

Wilson and McLaren (1972) 49 point out that frequent beat changes--such as common in the traditional, militaristic approach to law enforcement--prevent officer acquaintance with the persons, facilities, and hazards on his beat and interfere with continuity of service. Furthermore, it impedes the officer's understanding and sensitivity to the life styles and needs of the community.

Murphy and Bloch (1970) 50 indicate that stable assignment of police personnel to a neighborhood has positive effects on the community and on police-community relations. They go on to indicate that citizens get to know, identify, and have confidence in "their" police officers. Long term relationships are established, promoting citizen trust and a willingness on the part of citizens to report suspicious circumstances and criminal activity. Furthermore, Murphy and Bloch point out that:

- . stable assignment permits the officer to become familiar with an area and its trouble spots, enabling recognition of unexpected changes 51

490. W. Wilson and R. C. McLaren, Police Administration, 3rd ed. (New York: McGraw-Hill, 1972), p. 388. 50 Patrick V. Murphy and Peter B. Bloch, "The Beat Commander," Police Chief, XXXVII (May, 1970), p. 16. ${ }^{51_{\text {Ibid. }}, \mathrm{p} .18 .}$ 
In summary, the literature presented has been for the purpose of showing that Neighborhood Team Policing is a modern attempt by law enforcement agencies to reduce police isolation and involve the community in enforcing the laws. It has also been for the purpose of showing that providing assistance to people, both in handling crime related problems and in helping them make contact with the proper agencies to handle the myriad of other problems (for an example, family disputes), is one of the best means of achieving public support of and respect for police operations. 
CHAPTER IV

\section{RESEARCH DESIGN AND METHODOLOGY}

In order to provide descriptive data on the processes whereby the Niultnomah County Department of Public Safety sought to achieve community involvement, a design was developed in conjunction with the overall design developed by the Multnomah County Department of Public Safety to evaluate Neighborhood Team Policing. The design attempted to provide descriptive data on the performance of project activities as they relate to the achievement of the objectives of Goal 1 of the Neighborhood Team Policing Project.

The design consisted of three dimensions--what, how, and who. Each of these dimensions addressed past, present, and future activities engaged in by the Multnomah County Department of Public Safety in achieving the objectives of Goal 1 of the Neighborhood Team Policing Project. The three dimensions are:

Dimension 1-- What activities (past, present, and future) has the Department engaged in achieving the objectives of Goal 1 of the Neighborhood Team Policing Project?

Dimension 2--How (past, present, and future) did the Department go about achieving the objectives of Goal 1 of the Neighborhood Team Policing Project?

Dimension 3--Who (past, present, and future) was responsible for carrying out activities in achieving the 
objectives of Goal 1 of the Neighborhood Team Policing Project?

Population

The population was determined in consultation with the Neighborhood Team Policing Coordinator. It was determined that the population will consist of the Sheriff, his Executive Aide, the Team Managers, the Community Service Officers, the Evaluations Coordinator, the Project Trainers, the Public Information Officer, and the Sheriff's Secretary. The total number of persons was $18(\mathrm{~N}=18)$. These persons were selected because they were identified as key persons most closely associated with or assigned the responsibility for coordinating community involvement activities.

\section{Development of the Instrument}

The format used for data collection was an interview schedule. An interview schedule was chosen for several reasons. First of all, it could readily be administered to the small population determined by this study. Second of all, use of an interview schedule would minimize resistance and non-response. A third reason was that a large number of questionnaires had already been sent out by other persons engaged in evaluation of Neighborhood Team Policing; another questionnaire would increase the probability of non-returns.

In constructing the interview format, tasks found in the grant application which were related to community involvement were categorized. The categories determined 
were Public Information and Education, Training, and Community Involvement. Questions were then organized around these categories.

Questions \#1.1 - \#7.1 were designed to obtain information about Public Information and Education. For example, Question \#1.1 asked "Prior to July 1, 1975, was anything done to inform people that a new style of policing was about to take place in their community?" Question \#3.1 asked "How successful do you think the administrative process was in informing the public about Neighborhood Team Policing?" Question \#4.1 asked "Do you make a distinction between public information and public education?"

Question \#8.1 - \#12.1 were designed to obtain information about Training. For example, Question \#9.2 asked "Prior to implementation of Neighborhood Team Policing was any training provided officers to prepare them to become generalist police officers?" Question \#11.1 asked "After implementation of Neighborhood Team Policing, was any training provided officers that was based upon the concepts of human relations, community relations, and professionalisms?" Question \#12.1 asked "How successful do you believe the Department was in providing training to officers in order for them to assume new roles in Neighborhood Team Policing?"

Question \#13.1 - \#17.1 were designed to obtain information about Community Involvement. For example, Question \#14.1 asked "What does a community service officer do?" Question 
\#15.2 asked "Does your team have a written plan for involving the community in Neighborhood Team Policing?" Question \#16.1 asked "Has each team developed a profile of their respective neighborhoods?"

There were both open-end and closed-end questions. All open-end questions were designed with probes.

\section{Administration of the Instrument}

In preparing the respondents for the interview, a memorandum was sent to each one under the signature of the Sheriff. It explained briefly the purpose of the project and stated that the researchers would be contacting them to schedule a possible time for an interview.

The interviews were conducted during the weeks of March 22-26, 1976 and March 29-April 2, 1976. The time allotted for each interview was one hour and a half. Both researchers participated in the interviews, with one asking the questions and the other recording the responses. The interviews took place at the respondents' place of work.

\section{Data Analysis}

Frequency counts and percentages were used in analyzing responses to closed-end questions. Responses to open-end questions were categorized and coded according to whether they were the Sheriff's, the Evaluation Coordinator's, the Public Information Officer's, the Secretary's, the Team Managers', the Trainers', or the Community Service Officers'. 


\section{CHAPTER V}

\section{FINDINGS}

\section{Public Information and Education}

Prior to implementation of Neighborhood Team Policing, the Multnomah County Department of Public Safety felt it imperative that a public information and education strategy be developed to inform and educate the community to the change in the delivery of police services by the Department. In the Grant Application submitted to the United States Department of Justice Iaw Enforcement Assistance Administration, the Multnomah County Department of Public Safety's Team Police Planning Group delineated specific tasks that must be undertaken to insure the successful achievement of the goals and objectives of community involvement. Of the tasks delineated, three of them outlined a public information and education strategy. One of the tasks were to be completed prior to implementing Neighborhood Team Policing. The remaining two were to be undertaken following implementation of Neighborhood Team Policing. The tasks were:

1. Community Involvement Activities (Before July 1, 1975). Begin education toward citizen understanding of the Neighborhood Team Policing concept through public information. Develop media coverage, public appearance, and individual contact. 
2. Develop Public Education Program (August 1, 1975October 1, 1975). The objective of this task is to develop a program whereby the public can be informed of the change in the delivery of police services by the Department.

3. Conduct Public Information Program (October 1, 1975July 1, 1977). Based upon the plan developed under the above task, a public information program will be conducted for the duration of the project.

When asked "Prior to July 1, 1975, was anything done to inform people that a new style of policing was about to take place in their community?", 9 of the 18 respondents (50\%) indicated "yes". Eight of the 18 respondents indicated that "they did not know". This is shown in Table I.

Interviewers probed the response of those who answered "yes" to obtain further information. They indicated that television appearances were made by the Sheriff on the following stations:

Station

KATU-TV, Channel 2

KOIN-TV, Channel 6

KGW-TV, Channel 8

KPTV-TV, Channel 12

\section{Program}

"AM Northwest"

"Urban Focus"

"Watch Something Happen"

"Access"

"Impact"

"Mid-day News"

"Evening Show"

"Open Iine"

"East Side/West Side"

"Columbia Crossroads"

"\#12 Northwest"

"12 in the Morning"

The appearances were aired in the form of news segments, talk shows, spot announcements, and the like. They also indicated that there were radio broadcasts, press rap 
TABLE I

WERE PUBLIC INFORMATION ACTIVITIES CONDUCTED PRIOR TO INPIEIEENTATION OF

NEIGHBORHOOD TEAM POLICING?

\begin{tabular}{c|c|c|c|c}
\hline \hline Responses & Yes & No & Don't Know & Total \\
\hline Frequency & 9 & 1 & 8 & 18 \\
\hline Percentage & 50 & 6 & 44 & 100 \\
\hline
\end{tabular}

sessions, news articles carried by the major newspapers in Portland, and public appearances made by the Sheriff before recognized groups within the community. Groups before which public appearances were made include the PTA, the Gateway Elks Club, the Lions Club, the Rotary Club, the Kiwanis Club, and the Portland City Club.

The following response typifies the way 8 of 9 respondents felt who indicated that information activities had been engaged in prior to July 1, 1975:

There was no concentrated effort or formal program designed to inform the public about the Department's plan to implement Neighborhood Team Policing. Furthermore the activities engaged in were more of the oneshot, hit-or-miss type deals.

They indicated that almost all of the public information activities conducted prior to Neighborhood Team Policing were conducted by the Sheriff.

When asked "How successful they thought the administrative process was in informing the public about Neighborhood 
Team Policing?", 9 of the 18 respondents (50\%) indicated "moderately successful." There were 4 (22\%) who indicated "not very successful". Other responses are shown in Table II. As a follow-up to this question, interviewers asked "Why the administrative process was or was not successful?" Thirteen of the 18 persons (72\%) responded as to why the administrative process of informing the public was not successful. The response that most typifies those of the 13 respondents is the administrative process of informing the public about Neighborhood Team Policing prior to July 1, 1975, was not as successful as it could have been because there was a.lack of a planned strategy or program. Three of the 13 respondents indicated that this was due to the short period of time between the decision to implement Neighborhood Team Policing and actual implementation.

Since a public education program was to be developed following implementation of Neighborhood Team Policing,

\section{TABLE II}

HOW SUCCESSFUL RESPONDENTS FELT THE ADMINISTRATIVE PROCESS WAS IN INFORMING THE PUBLIC ABOUT NEIGHBORHOOD TEAM POLICING

\begin{tabular}{l|c|c|c|c|c}
\hline \hline Responses & $\begin{array}{c}\text { Very } \\
\text { Successful }\end{array}$ & $\begin{array}{c}\text { Moderately } \\
\text { Successful }\end{array}$ & $\begin{array}{c}\text { Not Very } \\
\text { Successful }\end{array}$ & Don't Know & Total \\
\hline Frequency & 3 & 9 & 4 & 2 & 18 \\
\hline Percentage & 16 & 50 & 22 & 12 & 100 \\
\hline
\end{tabular}


researchers sought to determine if the respondents made a distinction between public information and public education; and if so, what was the distinction. Ten of the 18 respondents $(56 \%)$ said they did make a distinction between public information and public education. The remaining 8 respondents (44\%) said they did not make a distinction. The response that most characterizes those of the 10 respondents who made a distinction between public information and public education is in a public information program material or information is disseminated to the public for them to assimilate as they wish; whereas, in a public education program persons to whom the material or information is disseminated are directed to assimilate or internalize it in a certain way. Two of the respondents who stated that they made a distinction between public information and public education indicated that a public information program has a broad focus; whereas, a public education program has a more narrow focus.

Respondents were asked "Was there a written plan for educating the public about Neighborhood Team Policing?" Responses to this question are shown in Table III.

The 3 respondents who indicated there was a written plan for educating the public about Neighborhood Team Policing were Team Managers. They pointed out that there was no written plan designed specifically for public education; but, there were written goals and objectives developed 
TABLE III

IS 'PHERE A WRITTEN PUBLIC EDUCATION PLAN?

\begin{tabular}{c|c|c|c|c}
\hline \hline Responses & Yes & No & Don't Know & Total \\
\hline Frequency & 3 & 9 & 6 & 18 \\
\hline Percentage & 16 & 50 & 34 & 100 \\
\hline
\end{tabular}

by their teams for bringing about community involvement within their specific team areas, and public education was one of the objectives.

The 9 respondents $(50 \%)$ who indicated that there was no written plan for educating the public about Neighborhood Team Policing stated that "some unwritten, or informal, activities had been performed by the Sheriff and by the teams." They included the following:

Informal Activities Performed by the Sheriff

1. Appearances made by the Sheriff at the opening of storefront offices.

2. A Sheriff's People Day held at the Department of Public Safety.

Informal Activities Performed by the Teams (Within Specific Areas)

1. Public appearances before local business organizations to explain Neighborhood Team Policing.

2. Public appearances before established groups to explain Neighborhood Team Policing.

3. Public appearances with school administrators to explain Neighborhood Team Policing. 
4. Public appearances at school general assemblies to explain Neighborhood Team Policing.

5. Individual contacts with citizens made by officers on the beat.

6. Pamphlets explaining Neighborhood Team Policing placed on school bulletin boards.

7. A brief explanation of Neighborhood qeam Policing sent to parents through school bulletins.

Along with the informal activities performed by the Sheriff and by the teams, 12 of the 18 respondents (67\%) indicated that the Crime Prevention Unit talked to persons about Neighborhood Team Policing in their block meetings on burglary.

Interviewers asked "If there was a public information program designed to be used for the duration of the Neighborhood Team Policing Project?" Responses to this question are shown in Table IV.

All of the 5 respondents who indicated that there was an on-going public information program stated that "the ongoing public information program was not a written or formal one." They indicated that it was on-going to the extent that

TABLE IV

IS THERE A WRITIEN ON-GOING PUBLIC INFORMATION PROGRAII?

\begin{tabular}{l|c|c|c|c}
\hline \hline Responses & Yes & No & Don't Know & Total \\
\hline Frequency & 5 & 4 & 9 & 18 \\
\hline Percentage & 28 & 22 & 50 & 100 \\
\hline
\end{tabular}


the Sheriff, the teams, and the Crime Prevention Unit would continue many of the public information activities in which they are currently engaging.

Training

The Multnomah County Department of Public Safety felt that training was an integral part of the community involvement aspect of Neighborhood Team Policing. In the Grant Proposal, the Team Police Planning Group delineated specific tasks that must be undertaken to insure that officers were provided with training necessary for them to assume their new roles in Neighborhood Team Policing. One of the tasks was to be completed prior to implementation of Neighborhood Team Policing and one was to be undertaken following implementation of Neighborhood Team Policing. The tasks were:

1. Praining (Before July 1, 1975). Develop training curriculum for all management consistent with participatory management objective. Provide inservice training for department members to improve skills required of generalist police officers. Training retreat for each team to develop team guidelines and objectives as a cohesive group and learn the appropriate community organization skills and group dynamics.

2. Conduct Team Training (August 1, 1975 - November 1, 1975). Since all members of the team have already been oriented to law enforcement training, this training will be designed to provide the officers with information, techniques, and principles to enable them to carry out responsibilities from the perspective of a model based upon the concepts of human relations, community relations, and professionalism.

With reference to training, researchers first sought to determine the respondents' definition of a generalist police 
officer. Eleven of the 18 respondents related the feeling that a generalist police officer is an officer qualified in all aspects of police service delivery. Five of the 18 respondents related the feeling that a generalist is a patrol officer not only responsible for initial investigation but also for follow-up investigation.

Respondents were then asked "How does a generalist police officer differ from a specialist police officer?" Thirteen of the 18 respondents answered in a similar fashion. They indicated that a specialist is a police officer trained and skilled in only one aspect of police work (e.g., patrolman conducts only preliminary investigation; detectives conduct follow-up investigations; only persons in scientific investigation dust for fingerprints, etc.). A response that typifies how 3 of the 18 respondents felt is that the scope of responsibilities are more narrow for the specialist police officer.

Respondents were asked "Prior to implementation of Neighborhood Team Policing, was any training provided officers to prepare them to become generalist police officers?" Responses to this question are shown in Table V. Interviewers probed the responses of those who indicated "yes" to find out more about the training that had been provided officers. All 7 respondents indicated that a one week training retreat was held for each team; the retreats took place at Manucha. Interviewers asked 
TABLE V

PRIOR TO NEIGHBORHOOD TEAM POLICING, WAS TRAINING PROVIDED OFFICERS TO PREPARE THEM TO BECOME GENERALIST POLICE OFFICERS?

\begin{tabular}{c|c|c|c|c}
\hline \hline Responses & Yes & No & Don't Know & Total \\
\hline Frequency & 7 & 7 & 4 & 18 \\
\hline Percentage & 39 & 39 & 22 & 100 \\
\hline
\end{tabular}

"What were the objectives of the training retreats?" The responses to this question and their frequency of occurrence are shown in Table VI. (Respondents could identify more than one objective. Hence, the frequency of responses will total more than 7.)

TABIE VI

OBJECPIVES OF THE TRAINING RETREATS

Response

Frequency

1. To allow the teams to develop a sense of team identity.

2. To involve team members in setting goals.

3. To allow officers to deal with anger and interpersonal problems.

4. To educate team members to participatory management philosophy.

5. To teach officers ways of handling their new job roles.

6. To define problems for specific team areas.

7. To teach officers how to handle an increased work load. 
The 7 respondents who indicated that training was provided officers through retreats held at Manucha were asked about the activities that took place at the retreats. Responses to this question and their frequency of occurrence are shown in Table VII. (Respondents could identify more than one objective. Hence, the frequency of responses will total more than 7. )

When asked "Prior to implementation of Neighborhood Team Policing, was anything done to develop a sense of cohesiveness among team members?", 13 of the respondents $(72 \%)$ indicated "yes" and 5 of the respondents (28\%) indicated "no".

Again interviewers probed to determine what activities were involved in "developing a sense of cohesiveness." All 13 respondents $(72 \%)$ who indicated that there were activities involved in developing cohesiveness pointed out that the main purpose of Manucha was an attempt to develop a sense of togetherness and team identity among team members. Respondents were asked "After implementation of Neighborhood Team Policing, was any training provided

TABLE VII

WHAT ACTIVITIES TOOK PLACE AT THE RETREATS?

\begin{tabular}{|c|c|}
\hline Response & Frequency \\
\hline 1. Unstructured activities & 7 \\
\hline 2. Recreational activities & 6 \\
\hline 3. Groun discussions & 6 \\
\hline 4. Rap sessions & 4 \\
\hline 5. Iectures & 2 \\
\hline
\end{tabular}


officers that was based upon the concepts of human relations, community relations, and professionalism?" Responses to this question are shown in Table VIII.

The 8 respondents who indicated that training was provided officers pointed out that there was "An Understanding People Seminar" held once a week to provide officers with knowledge of human behavior and psychological theory. The training was provided by a local psychiatrist and consisted of lectures, observations of interviews with clients, and role playing. The training took place at the Hansen Health Building.

Seven of the 18 respondents (39\%) indicated that the Crime Prevention Unit provided training to Community Service Officers. The training provided Community Service Officers was conducted once a week and lasted for a period of two months. It consisted of an attempt to provide Community Service Officers with knowledge and skills in community relations.

The 18 respondents were asked "How successful the

TABLE VIII

AFTER IMPLEMENTATION OF NEIGHBORHOOD TEAM POLICING, WAS HUNAAN REIATIONS TRAINING PROVIDED OFFICERS?

\begin{tabular}{l|c|c|c|c}
\hline \hline Responses & Yes & No & Don't Know & Total \\
\hline Frequency & 8 & 5 & 5 & 18 \\
\hline Percentage & 44 & 28 & 28 & 100 \\
\hline
\end{tabular}


Department had been in providing training to officers in order for them to assume new roles in Neighborhood Team Policing?" Responses to this question are shown in Table IX. As a follow-up to the above question, interviewers asked "Why the Department was or was not successful in providing the training to officers?" The response that characterizes the way most persons felt was that the training was not as successful as it could have been because of a lack of time and resources (consultants to lay out a training program).

\section{Cormunity Involvement}

This category was designated as community involvement because there were tasks identified in the Grant Application which defined, very specifically, attempts that would be made to actively involve citizens in Neighborhood Team Policing. The tasks were to be undertaken following

TABLE IX

HOW SUCCESSFUL RESPONDENTS FELT THE ADMINISTRATIVE PROCESS WAS IN PROVIDING OFFICERS WITH HUMAN RELAPIONS TRAINING

\begin{tabular}{l|c|c|c|c|c}
\hline \hline Responses & $\begin{array}{c}\text { Very } \\
\text { Successul }\end{array}$ & $\begin{array}{c}\text { Noderately } \\
\text { Successful }\end{array}$ & $\begin{array}{c}\text { Not Very } \\
\text { Successful }\end{array}$ & Don't Know & Total \\
\hline Frequency & 2 & 8 & 4 & 4 & 18 \\
\hline Percentage & 12 & 44 & 22 & 22 & 100 \\
\hline
\end{tabular}


implementation of Neighborhood Team Policing. They are as follows:

1. Develop Community Change Process Plan (August 1, 1975 - October 1, 1975). The purpose of this task is to develop a plan whereby the community can be involved in this new style of policing. Both consultants and the community will assist in carrying out this task.

2. Establish Community Service Officer Program (January 1, 1976 - April 1, 1976). The purpose of this task will be to establish a position of community service officer in the department. Those appointed will be responsible for performing non-law enforcement functions, with special emphasis on services to the victims of crime.

3. Develop Community Involvement Plan (December 1, 1975 - April 1, 1976). Under this task, each team will develop its community involvement plan. The exact content of the plan will be left up to the teams. They will consider, for example, neighborhood advisory committees, regular community meetings, etc.

4. Develop Neighborhood Profiles (October 1, 1975 July 1, 1976). Under this task, each team will be required to develop a profile of their respective neighborhoods. This analysis will be used by the teams in developing their style of policing and programs.

5. Develop Linkages With Social Service Agencies (December 1, 1975 - July 1, 1977). The purpose of this task will be to develop linkages and establish working relationships with social service agencies. The objective will be to bring to bear the total resources of the community.

Respondents were asked "What is a community change process plan?" Fifteen of the 18 respondents (83\%) indicated that they "did not know" what a community change process plan was. Three of the respondents defined the concept of a community change process plan. The definition 
most reflective of the three person's responses is a community change process plan is a strategy designed to measure the impact of change upon a community.

As a follow-up to the above questions, interviewers asked "Is there a written Community Change Process Plan?" Responses to this question are shown in Table $X$.

Interviewers wanted to obtain information about the Community Service Officer Program. Respondents were asked "What does a Community Service Officer do?" Responses to this question and their frequency of occurrence are shown in Table XI. (Respondents could give more than one response. Hence, the frequency of responses will total more than 18.)

Team Managers and Community Service Officers were asked questions about the community involvement plan that each team was to develop. Interviewers first asked "How does your team define community involvement?" The definition most typical of the responses of 2 of the Team Managers is that community involvement is developing more individual officer contact with people in the community. One Team Manager defined community involvement as police involvement in

TABLE X

IS THERE A WRITTEN COMINUNITY CHANGE PROCESS PIAN?

\begin{tabular}{l|c|c|c|c}
\hline \hline Responses & Yes & No & Don't Know & Total \\
\hline Frequency & -- & 8 & 10 & 18 \\
\hline Percentage & -- & 44 & 56 & 100 \\
\hline
\end{tabular}


'LABLE XI

WHAT DOES A CONMUNITY SERVICE OFFICER DO?

\begin{tabular}{|c|c|}
\hline Response & Frequency \\
\hline $\begin{array}{l}\text { 1. Collect data on demographic character- } \\
\text { istics of the community. } \\
\text { 2. Provide assistance in the form of com- } \\
\text { munity involvement activities. } \\
\text { 3. Serves as a referral person for the } \\
\text { teams. } \\
\text { 4. Serves as a liaison between the Depart- } \\
\text { ment and the community. } \\
\text { 5. Administer surveys to businesses and } \\
\text { established leadership groups within } \\
\text { the community. } \\
\text { 6. Roles of Community Service officers are } \\
\text { unclear. }\end{array}$ & $\begin{array}{r}10 \\
10 \\
8 \\
8\end{array}$ \\
\hline
\end{tabular}

problems which are not "real" police work (e.g. family beefs). The definition most reflective of the way the remaining two Team Managers defined community involvement is that community involvement entails identifying all persons in the community who are established leaders and engaging them in defining ways of working together to solve community problems. The definition most characteristic of the way 3 of the 5 Community Service Officers defined community involvement is that community involvement consists of police participation in non-criminal activities. The remaining 2 Community Service Officers did not know how their teams defined community involvement.

When asked "Does your team have a written plan for involving the community in Neighborhood Team Policing?", 
all 5 of the Team Managers indicated "yes". Two of the 5 Community Service Officers also indicated "yes". Three of the Community Service Officers indicated that they "did not know" if their teams had a written plan for involving the community in Neighborhood Team Policing. All of the 5 Team Managers indicated that community involvement activities to this point have been performed on an informal basis.

The respondents were asked "Has each team developed a profile of their respective neighborhoods?" Responses to this question are shown in Table XII.

Team Managers and the Community Service Officers indicated that the teams were in the process of developing the profiles. Three of the respondents indicated that a Social Area Analysis Task Force was established shortly after implementation of Neighborhood Team Policing for the purpose of developing the profiles. They indicated that the report was not yet completed. One respondent pointed out that demographic data was gathered initially (prior to implementation of Neighborhood Team Policing) to determine team boundaries.

\section{TABLE XII}

HAS EACH TEAIV DEVELOPED A PROFILE OF THEIR RESPECTIVE NEIGHBORHOODS?

\begin{tabular}{l|c|c|c|c}
\hline \hline Responses & Yes & No & Don't Know & Total \\
\hline Frequency & 3 & 15 & - & 18 \\
\hline Percentage & 17 & 83 & -- & 100 \\
\hline
\end{tabular}


When asked "What activities are involved in developing linkages and establishing working relationships with social service agencies?", all 18 respondents indicated that formal relationships had not been established with social service agencies. Five of the 18 respondents (28\%) responded in a similar fashion, commenting that services from other agencies are usually requested only in emergency situations. One Team Manager indicated that a Memorandum of Understanding has been sent out to Children Services Division and the schools by the Department. Another of the Team Managers pointed out that their team is in the process of compiling a booklet of social service agencies to be used as a referral source. 
CHAPTER VI

SUMVAARY, CONCLUSIONS, AND INTERPRETATIONS

This study has described the activities engaged in by the Multnomah County Department of Public Safety in an attempt to bring about community involvement. This chapter will sumnarize the study's findings and indicate some conclusions and interpretations they suggest relative to three questions: (1) Did the Multnomah County Department of Public Safety carry out the task specified in the Grant Proposal which related to community involvement? (2) Did the Multnomah County Department of Public Safety carry out the task specified in the Grant Proposal which related to community involvement within the stated time period? (3) What factors contributed to the Multnomah County Department of Public Safety's failure to carry out a specified task? The summary, conclusions, and interpretations will be organized around the three categories of tasks (public information and education, training, and community involvement).

Public Information and Education

To summarize the findings about public information and education, data showed that 8 of the persons interviewed (44\%) were unaware of any attempt by the Department of Public 
Safety, prior to July 1, 1975, to inform the community about the change in the delivery of police services by the Department. Data also showed that of the 9 respondents who were aware of the attempt by the Department of Public Safety, prior to July 1, 1975, to inform the community about the change in the delivery of police services, 8 felt that there was no concentrated effort or formal program designed by the Department.

This would support the conclusion that although the Multnomah County Department of Public Safety engaged in a number of activities prior to July 1, 1975, to inform the public about the implementation of Neighborhood Team Policing, there was no planned strategy or program. The task in the Grant Proposal did not state that the Department would develop a planned strategy or formal public information program prior to July 1, 1975, but researchers concluded that lack of such could have resulted in communication problems which may have led to duplication of services and inefficient utilization of time and resources. When asked "How successful they thought the administrative process was in informing the public about Neighborhood Team Policing?", 9 of the respondents (50\%) indicated "moderately successful". Four of the respondents (22\%) indicated "not very successful". However, when asked "Why the administrative process was or was not successful?", 13 respondents (the 9 who indicated "moderately successful" 
and the 4 who indicated "not very successful") commented as to why the administrative process was not successful rather than why it achieved some degree of success.

This would seem to indicate that respondents felt more dissatisfied with the public information and education activities engaged in by the Department than they had indicated in the closed-end question.

Data showed that 9 of the respondents (50\%) pointed out that there was no written plan for educating the public about Neighborhood Team Policing. Six of the respondents (34\%) did not know if there was a written plan for educating the public about Neighborhood Team Policing. Data also showed that 8 of the respondents $(44 \%)$ did not make a distinction between public information and public education. This led researchers to conclude that following implementation of Neighborhood Ieam Policing, it was likely two distinct programs (a public information program and a public education program) were not developed because a clear distinction was not made between the two programs.

One-half of the respondents (50\%) indicated that they "did not know" if there was an on-going public information program. Four of the respondents (22\%) indicated that there was no on-going public information program. Because of this, researchers felt that the public may not be receiving adequate information about Neighborhood Team Policing. It seems that in carrying out the task related to 
public information and education, the Department's activities appeared to have been "on-the-surface." It is difficult in a study of this nature to determine reasons why. However, researchers suggest that a number of factors are involved. These include lack of planning and administration, lack of manpower, insufficient economic resources, and lack of interest on the part of many Department personnel.

Training

To summarize the findings about training, data showed that 7 of the 18 respondents $(39 \%)$ indicated that prior to implementation of Neighborhood Team Policing, training had been provided officers to prepare them to become generalist police officers. Almost three-fourths of the respondents (72\%) indicated that an attempt was made to develop a sense of cohesiveness among team members. Respondents cited the training that took place at Manucha was an attempt to provide officers with training to prepare them to become generalist and an attempt to develop a sense of cohesiveness among team members.

This would seem to indicate that the Manucha training served more to develop a sense of togetherness among team members. Also, it seems likely that the Department was successful to some degree in its attempt to provide teams with the opportunity to develop team cohesiveness and identity before actually being required to function as 
neighborhood teams.

Although some training was provided officers through the Nanucha retreats to prepare them to become generalist, respondents indicated that no in-service training was provided officers prior to Neighborhood Team Policing which would serve to achieve such purpose. Therefore, it was likely that officers entered Neighborhood Team Policing with specialist skills.

Eight of the respondents (44\%) indicated that after implementation of Neighborhood Team Policing officers were provided with training based upon the concepts of human relations, community relations, and professionalism. Responderits pointed out that "An Understanding People Seminar" was held once a week to provide officers with knowledge of human behavior. The seminars are on-going. However, although no data was obtained which showed how many officers participated in the seminars, researchers learned through informal means that only a very limited number of officers were able to participate in the prograil. Also, 4 of the respondents (22\%) pointed out that the seminars were not specifically designed as a strategy to achieve the task related to community relations and human relations training. It seems likely, then, that following implementation of Neighborhood Team Policing very little, if any, training was provided officers from the perspective of a model based upon the concepts of human 
relations, community relations, and professionalism.

Conmunity Involvement

Data showed several important findings about task related to community involvement. To summarize, more than three-fourths of the respondents $(83 \%)$ did not know what a community change process plan was. This would seem to suggest that it was likely the community change process plan was not developed.

With reference to the Community Service Officer Program, data showed that the position of Community Service Officer had been established in the Department. The position was established and funded through the Comprehensive Employment Training Act (CETA). Data also showed that expectations and functions of the Community Service Officer were clear to them as well as other Department members. Ihis would support the conclusion that the task of establishing a Community Service Officer Program had been carried out.

Each of the five leam Managers indicated that their team had a written plan for involving the community in Neighborhood Team Policing and that the plan had been implemented. Again, this led researchers to conclude that the task of developing a community involvement plan had been carried out. Eighty-three percent of the respondents indicated that each team had not developed a profile of their 
respective neighborhoods. However, this task was not scheduled to be completed until July 1, 1976. Furthermore, data showed that a Social Area Analysis Task Force had been set up shortly after implementation of Neighborhood Team Policing to begin developing the profiles. (Some demographic data of each team area had been compiled.) Teams are also making efforts through the Community Service Officers to develop their team profile. It seems, then, that the task of developing neighborhood profiles will be accomplished by the target date.

Finally, findings showed that the Department of Public Safety did not develop linkages and establish working relationships with other social service agencies. In fact, all 18 respondents indicated that contacts with other agencies were made only in emergency situations. Again, reasons for the Department not developing linkages and establishing working relationships with other social service agencies are difficult to determine in this type of study. However, researchers conclude that it is likely that factors are involved similar to those mentioned earlier in this study. Most importantly, these are lack of manpower and time. 


\section{BIBLI OGRAPHY}

Alex, Nicholas. Black in Blue: A Study of the Negro Policeman. New York: Harper and Row Publishers, 1967.

Angell, John E. "Toward an Alternative to the Classic Police Organizational Arrangements: A Democratic Model," Criminology, IX (August-November, 1971).

Badalaments, Richard $V$. et al. "Training Police for Their Social Role," Journal of Police Science and Administration, I (December, 1973).

Bard, Morton. "Family Intervention Police Teams as A Community Mental Health Resource," The Journal of Criminal Law, Criminology, and police Science, IX (June, 1969).

Bard, Morton and Berkowitz, B. "A Community Consultation Program in Police Family Crisis Intervention: Preliminary Impressions," International Journal of Social Psychiatry, XV (Summer, 1969).

Bell, Robert I. et al. "Small Group Dialogue and Discussion: An Approach to Police-Community Relationships," The Journal of Criminal Law, Criminology, and Police Science, Ix (June, 1969).

Black, D. J. "Police Encounters and Social Organization: An Observation Study." Ph.D. Dissertation, Department of Sociology, University of Michigan, 1968.

Block, Peter and Specht, David. Prescriptive Package: Neighborhood Team Policing. Washington, D.C.: Government Printing Office, 1973.

Borocas, Harvey and Katz, Myron I. "Dayton's Pilot Training Program: Crisis Intervention," Police Chief, XXXVIII (July, 1971).

Cumming, Elaine et al. "Policeman as Philosopher, Guide, and Friend" Social Problems, XII (Winter, 1965).

Eiphross, P. H. and French, P. "Social Service and the Police," Hospital and Community Psychiatry, XXIII (January, 1972). 
Epstein, Charlott. Intergroup Relations for Police Officers. Baltimore, Maryland: Williams and Wilkins Company, 1962 .

Germann, A. C. "Community Policing: An Assessment," The Journal of Criminal Law, Criminology, and Police Science, IX (March, 1969).

Golembiewski, Robert T. Organizing Men and Power: Patterns of Behavior and Iine and Staff Models. Chicago: Rand McIVally, 1967.

Gourley et al. "Patrol Specialization vs. Generalization," Effective Police Organization and Management, IV (October, 1966).

Johnson, Deborah and Gregory, Robert J. "Police-Community Relations in the United States: A Review of the Iiterature and Projects," The Journal of Criminal Law, Criminology, and Police Science, IXII (June, 1971).

Kenney, John P. "Team Policing Organization: A Theoretical Model," Police, IV (August, 1972).

Koverman, Robert B. "Team Policing: An Alternative to Traditional Law Enforcement Techniques," Journal of Police Science and Administration, II (March, 1974).

Lundman, Richard J. "Domestic Police-Citizens Encounters," Journal of Police Science and Administration, II (Niarch, 1974).

Martin, Edgar E. et al. "Multnomah County Department of Public Safety $\overline{\mathrm{Ne}}$ ighborhood Team Policing Grant Proposal: Program Narrative." Multnomah County, Oregon, 1975.

Mills, Robert B. "Use of Diagnostic Small Groups in Police Recruit Selection and Training," The Journal of Criminal Law, Criminology, and Police Science, LX (June, 1969).

Multnomah County Department of Public Safety Proposed Neighborhood l'eam Policing Evaluation Design. Multnomah County, Oregon, 1976.

Murphy, Patrick V. and Bloch, Peter B. "The Beat Commander," Police Chief, XXXVII (May, 1970).

Myren, Richard A. "Decentralization and Citizen Participation in Criminal Justice Systems," Public Administration Review, XXXII (October, 1972). 
National Advisory Commission On Criminal Justice Standards and Goals. A Strategy to Reduce Crime. Washington, D.C.: Government Printing Office, 1973.

National Advisory Commission On Criminal Justice Standards and Goals. Police: Task Force Report. Washington, D.C.: Govermment Printing Office, 1973.

National Sheriff's Association. Issues in Team Policing: A Review of the Literature. Washington, D.C.: U.S. Department of Justice, 1975.

Phelps, Lourn G. et al. "Training an Entire Patrol Division in Domestic Crisis Intervention Techniques," Police Chief, XXXVIII (July, 1971).

Police Consolidation Project. Staff Report, V. Portland, Oregon: Police Consolidation Project, 1974.

President's Commission on Law Enforcement and Administration of Justice. The Challenge of Crime in A Free Society. Washington, D.C.: Government Printing Office, 1967.

Sandler, George B. and Mintz, Ellen. "Police Organizations: Their Changing Internal and External Relationships," Journal of Police Science and Administration, II (December, 1974).

Trojanowicz, Robert C. "Police-Community Relations: Problems and Process," Criminology, IX (February, 1972).

Webster, J. A. "Police Task and Time Study," The Journal of Criminal Law, Criminology, and Police Science, II (March, 1970).

Whitehouse, Jack E. "Historical Perspective On PoliceCommunity Service Function," Jourmal of Police Science and Administration, I (March, 1973).

Wilson, O. W. and McLaren, R. C. Police Administration. 3rd ed. New York: McGraw-Hill, 1972. 
APPENDIX A

GOALS AIND OBJECTIVES OF CONMUNITY INVOLVEMENT

Goals

To improve police-community mutual involvement and problem-solving.

Objectives

1. To increase police-community interaction through intensive community involvement as a logical extension of the participatory management concept.

2. To improve police-community relations through intensive community involvement in the programs of operation of the department.

3. To carry out the police function by utilizing techniques and principles derived from human relations, community relations, and professional models of working with people.

4. To increase the cooperation and collaboration between the department and social service agencies in the cause of crime prevention and control.

5. To increase participation in decision-making and planning at the team and neighborhood level.

6. To rely on information to control crime rather than on street stops and other patrol techniques that might jeopardize police-community relations.

7. To reduce and/or control the incidence of crime through improved community involvement and better utilization of departmental resources. 


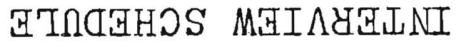

g XIQNifdd 


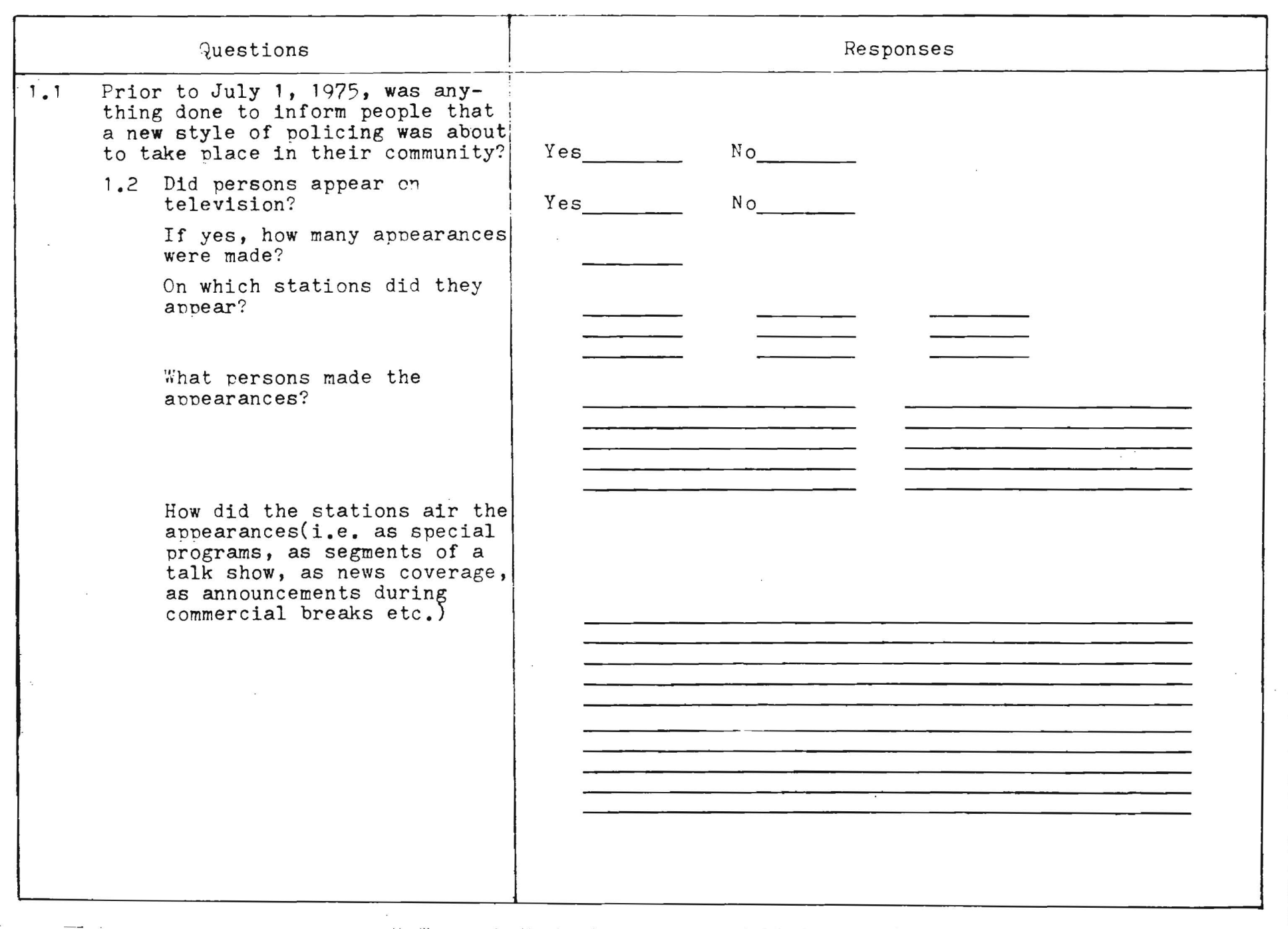




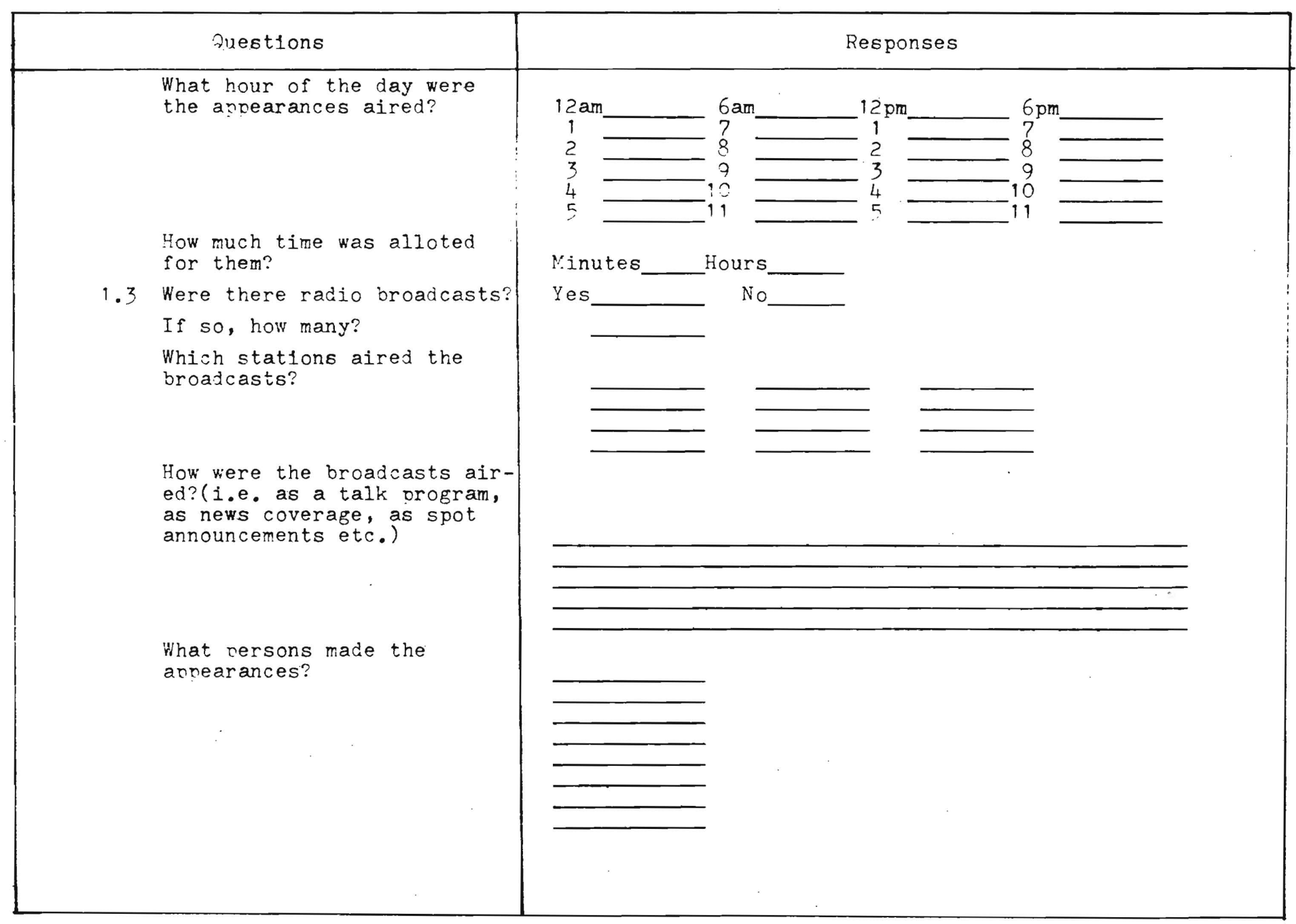




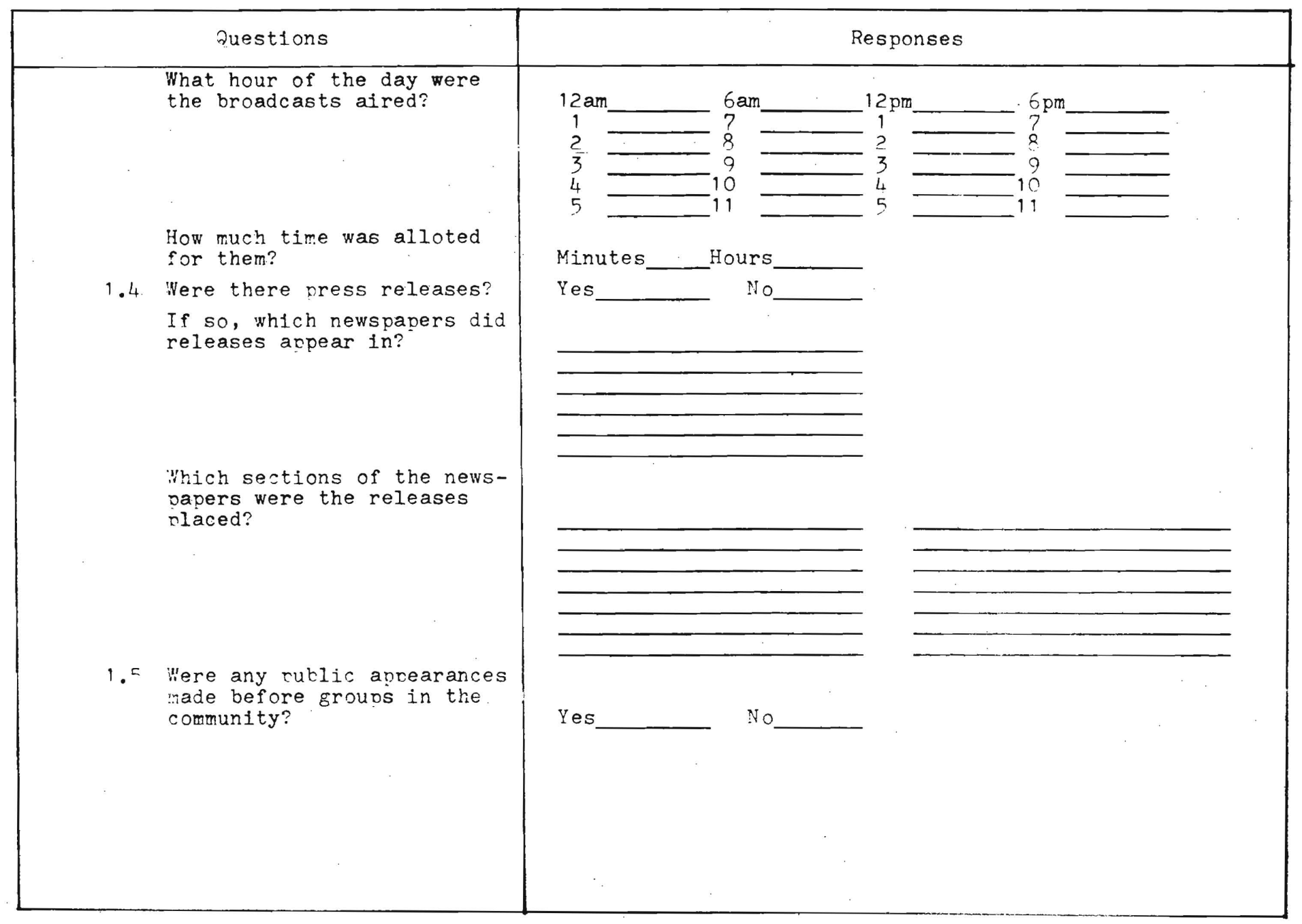




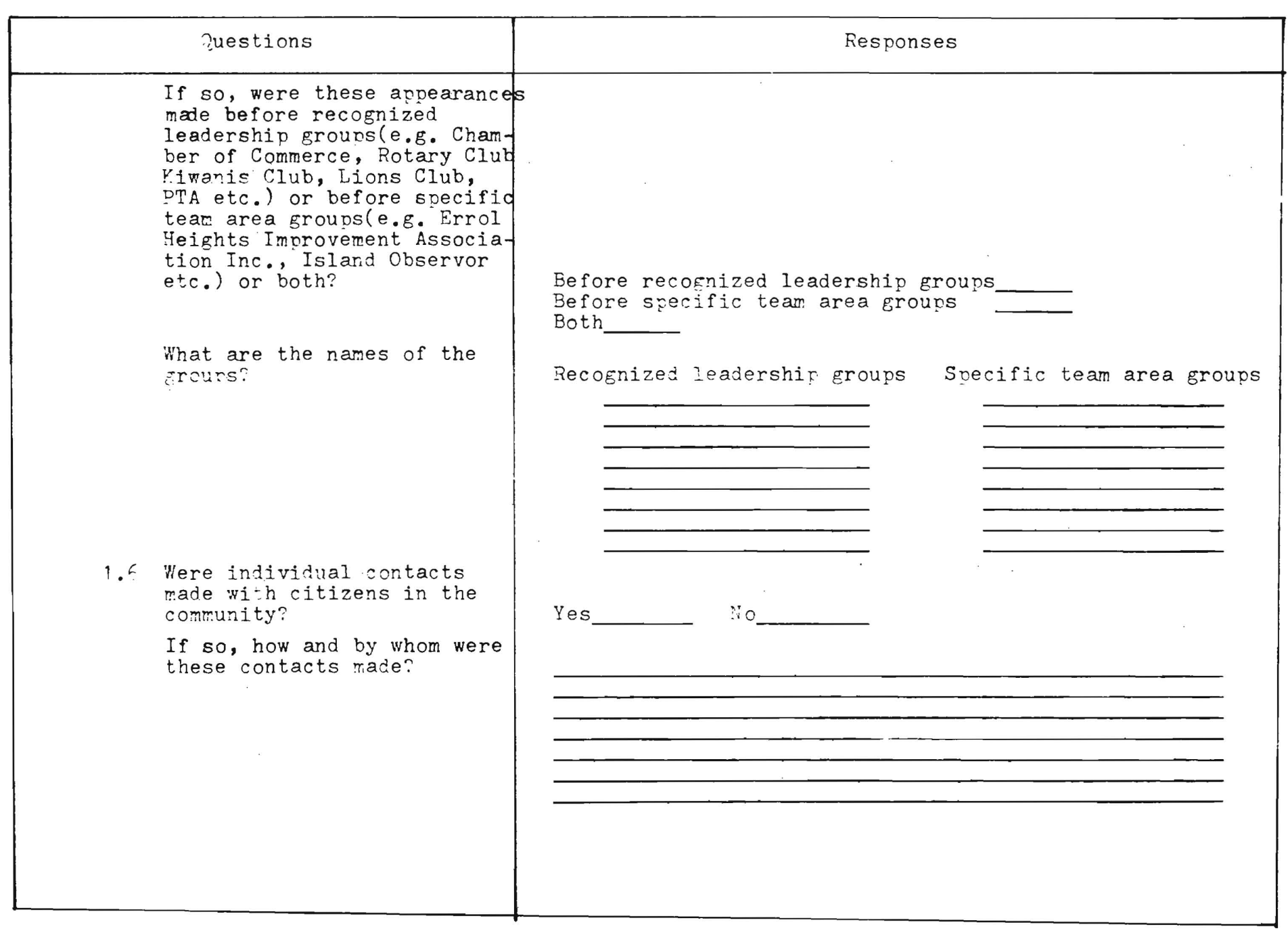




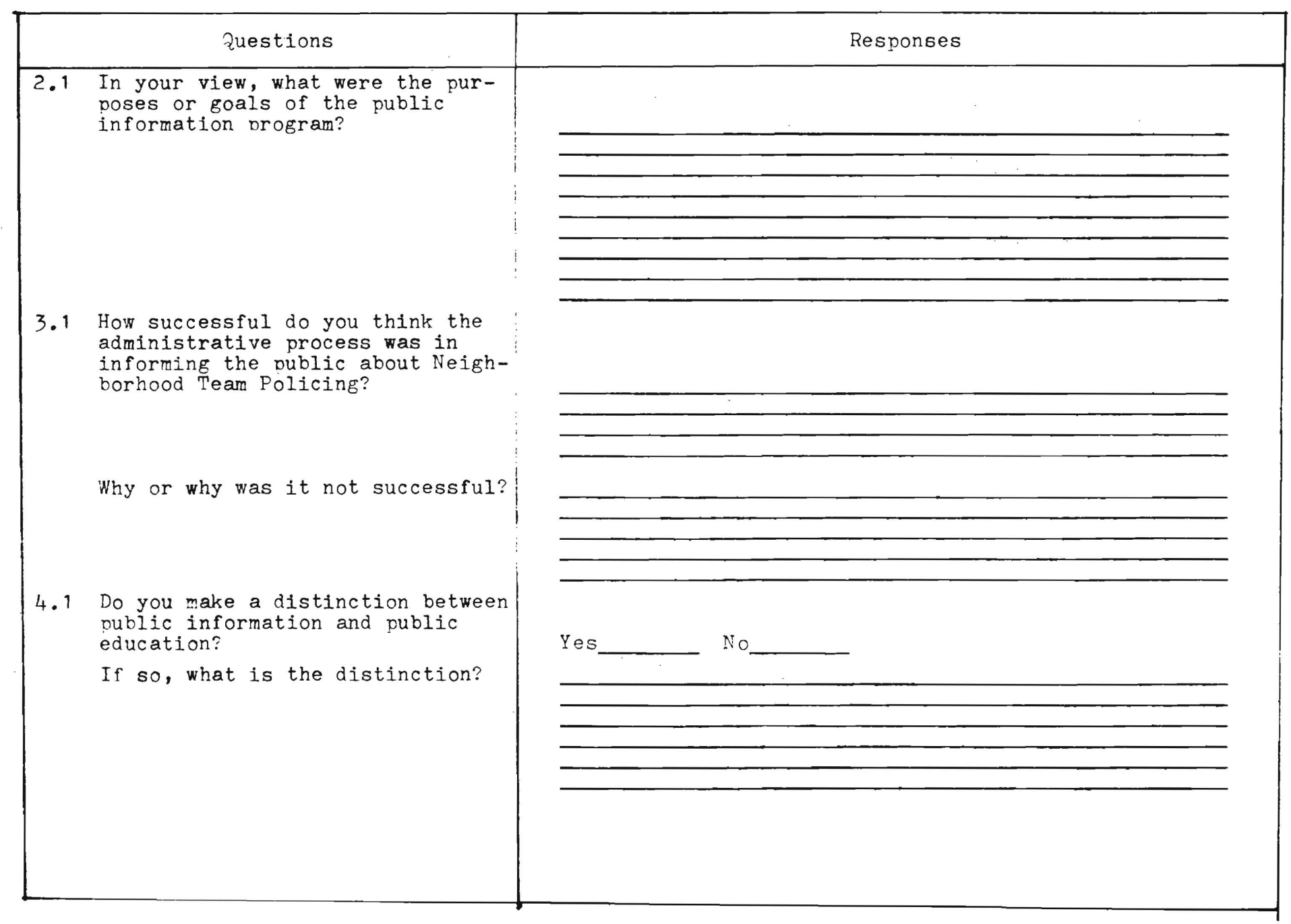




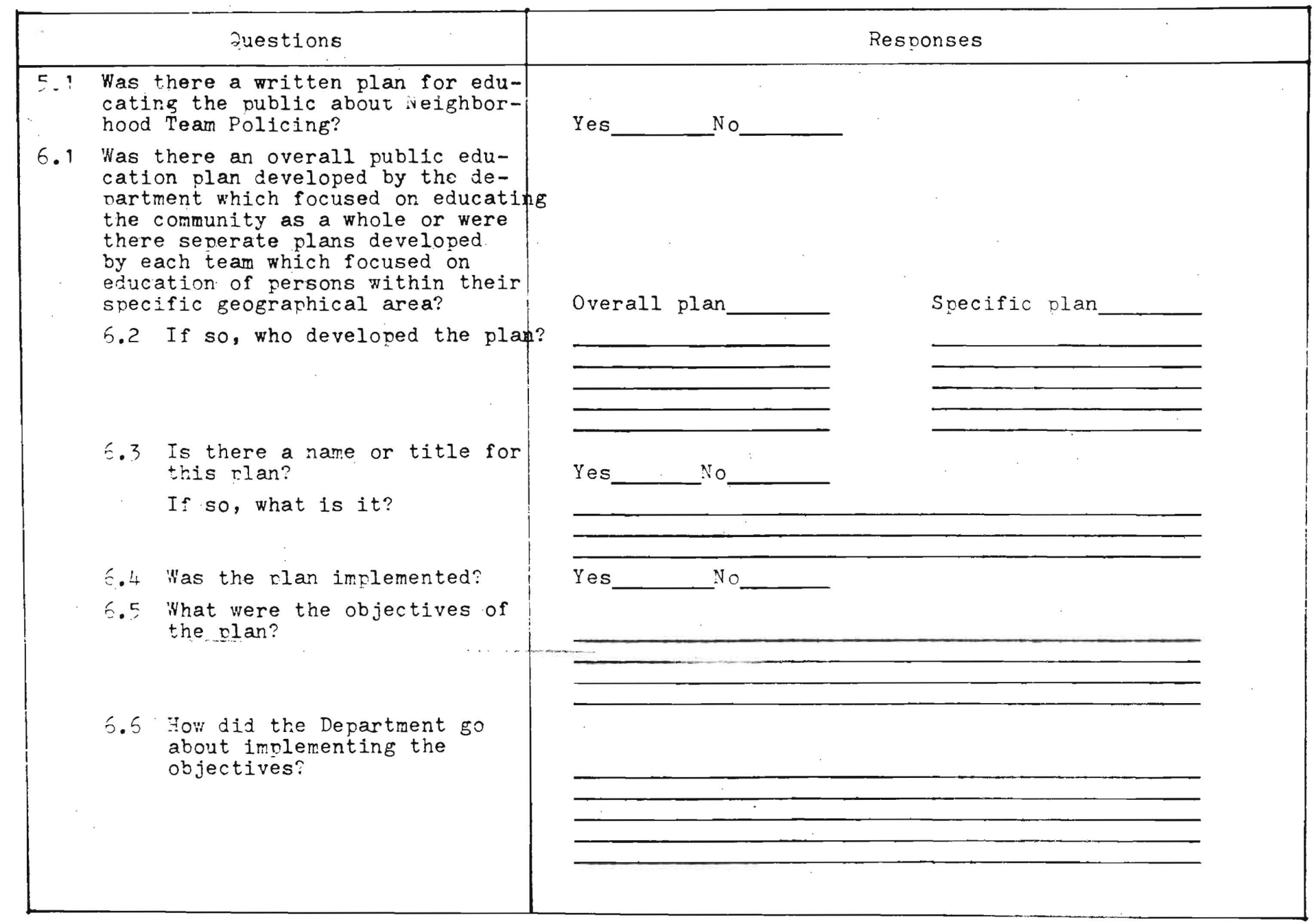




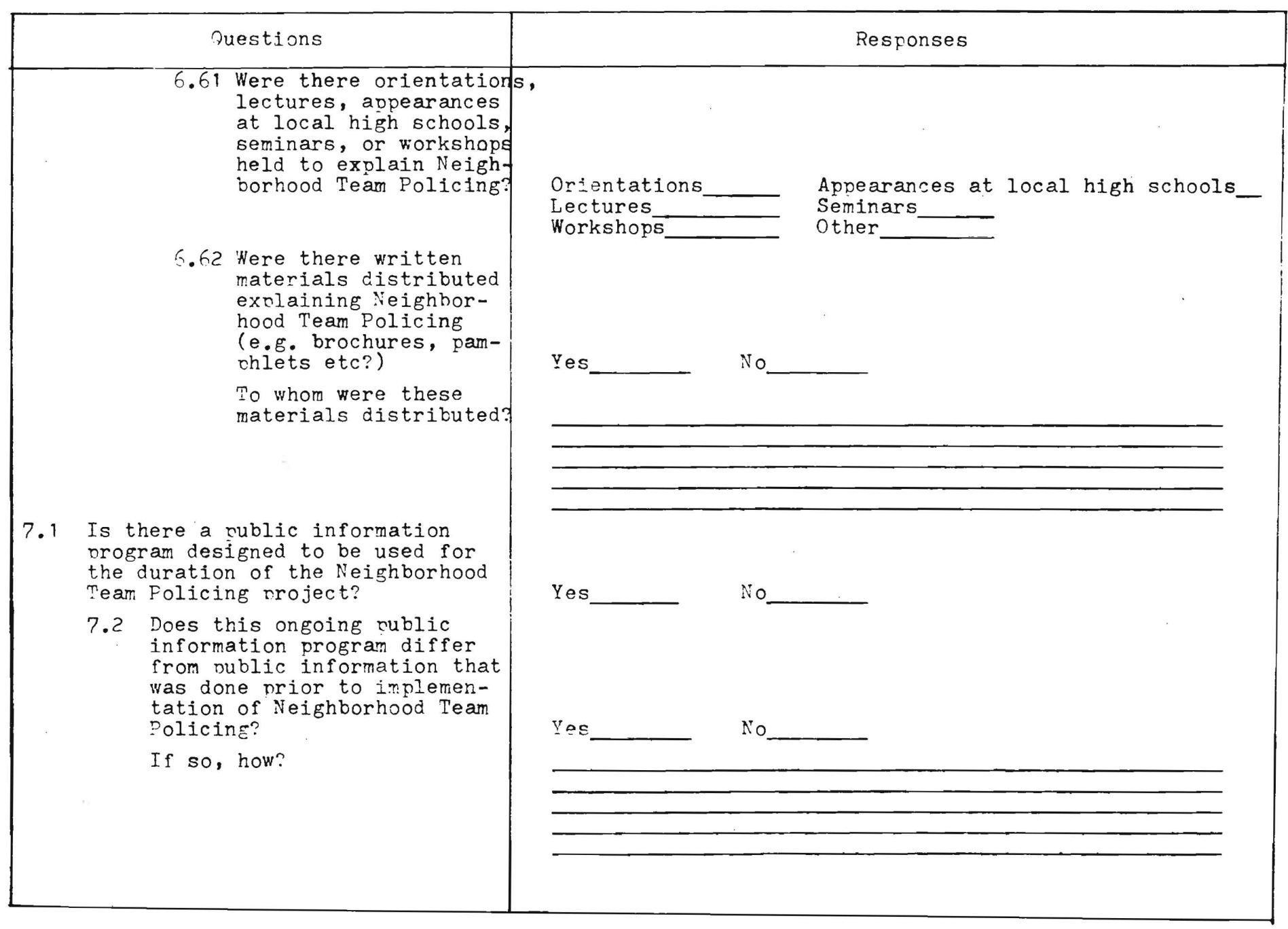




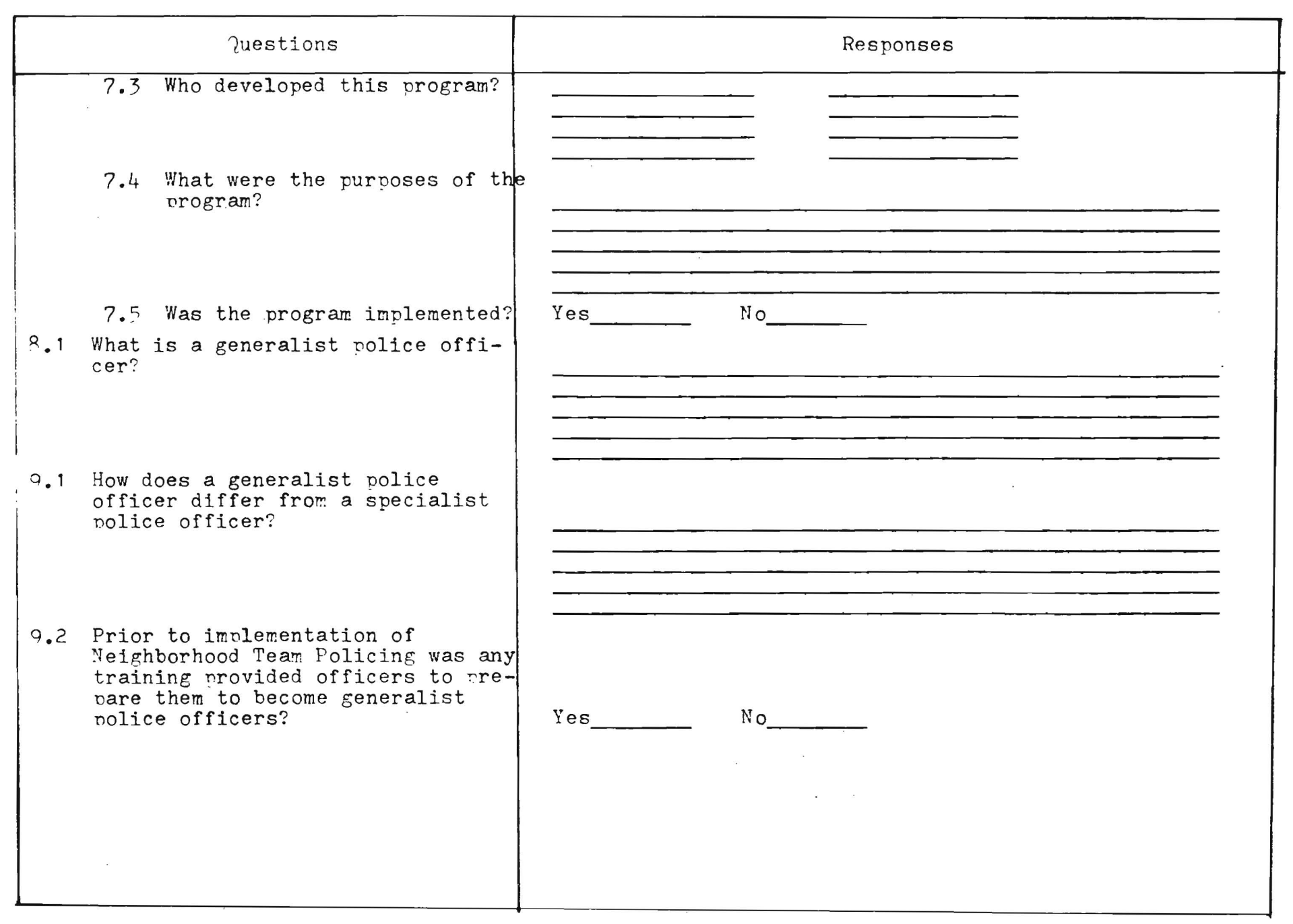




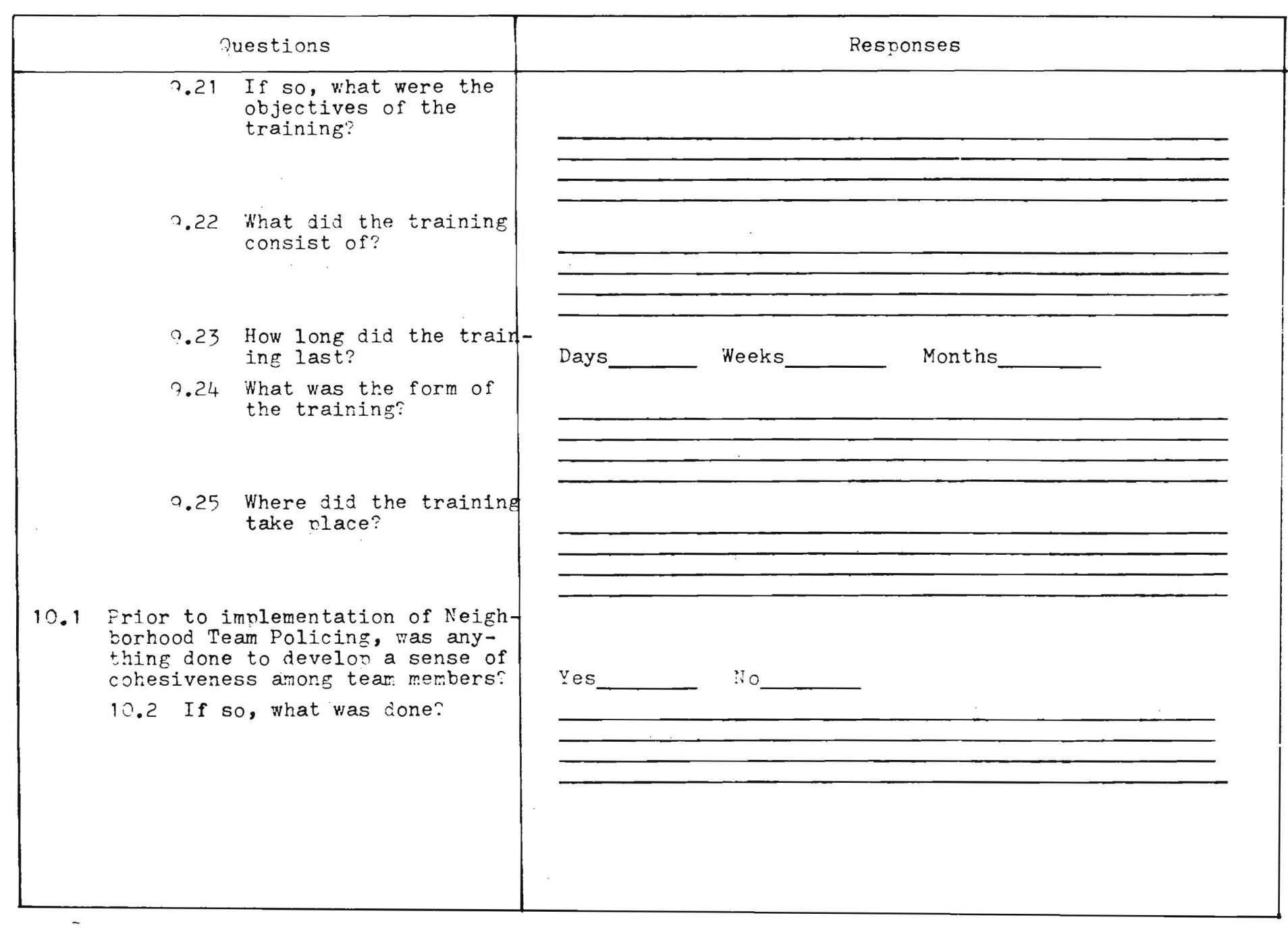




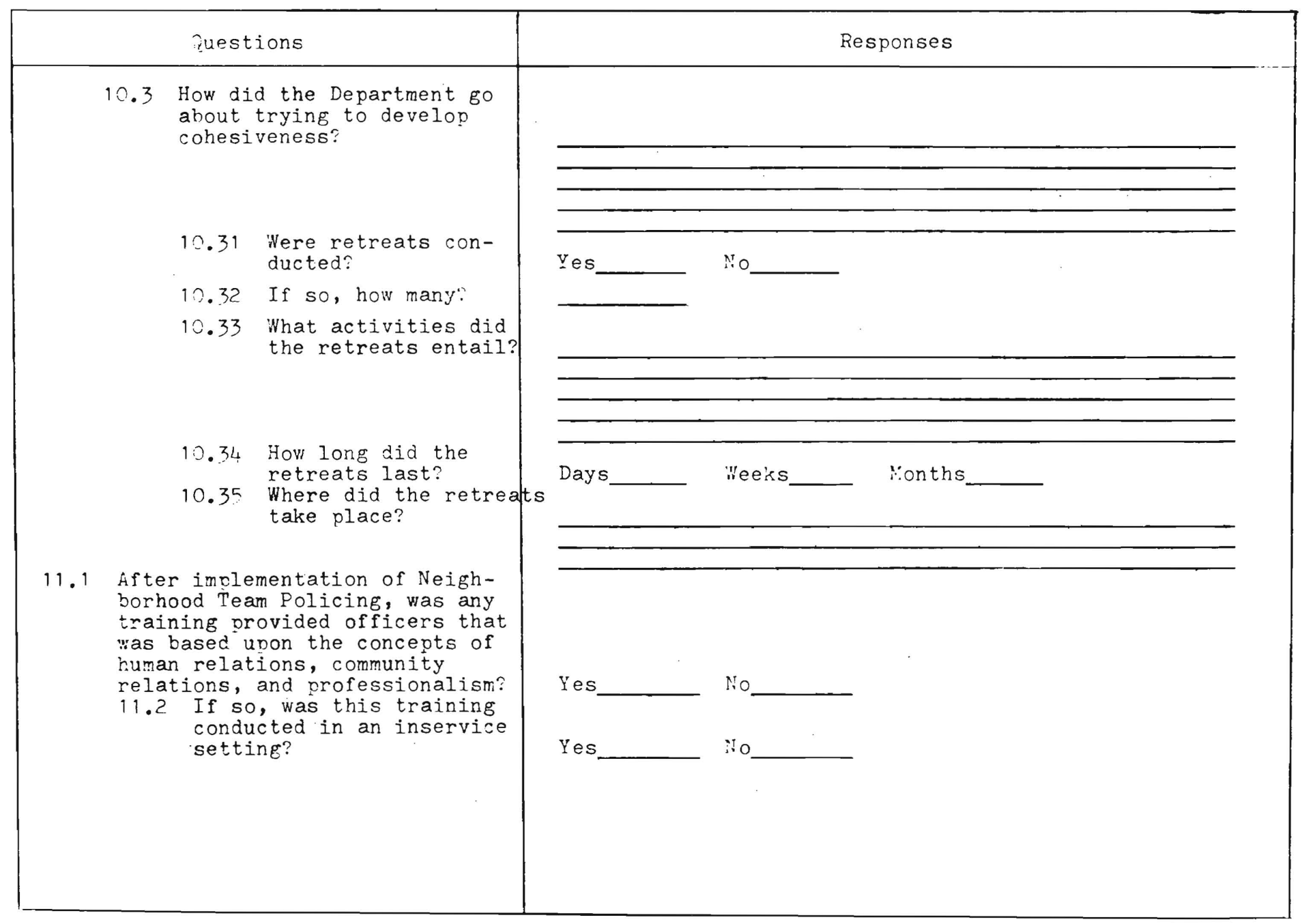




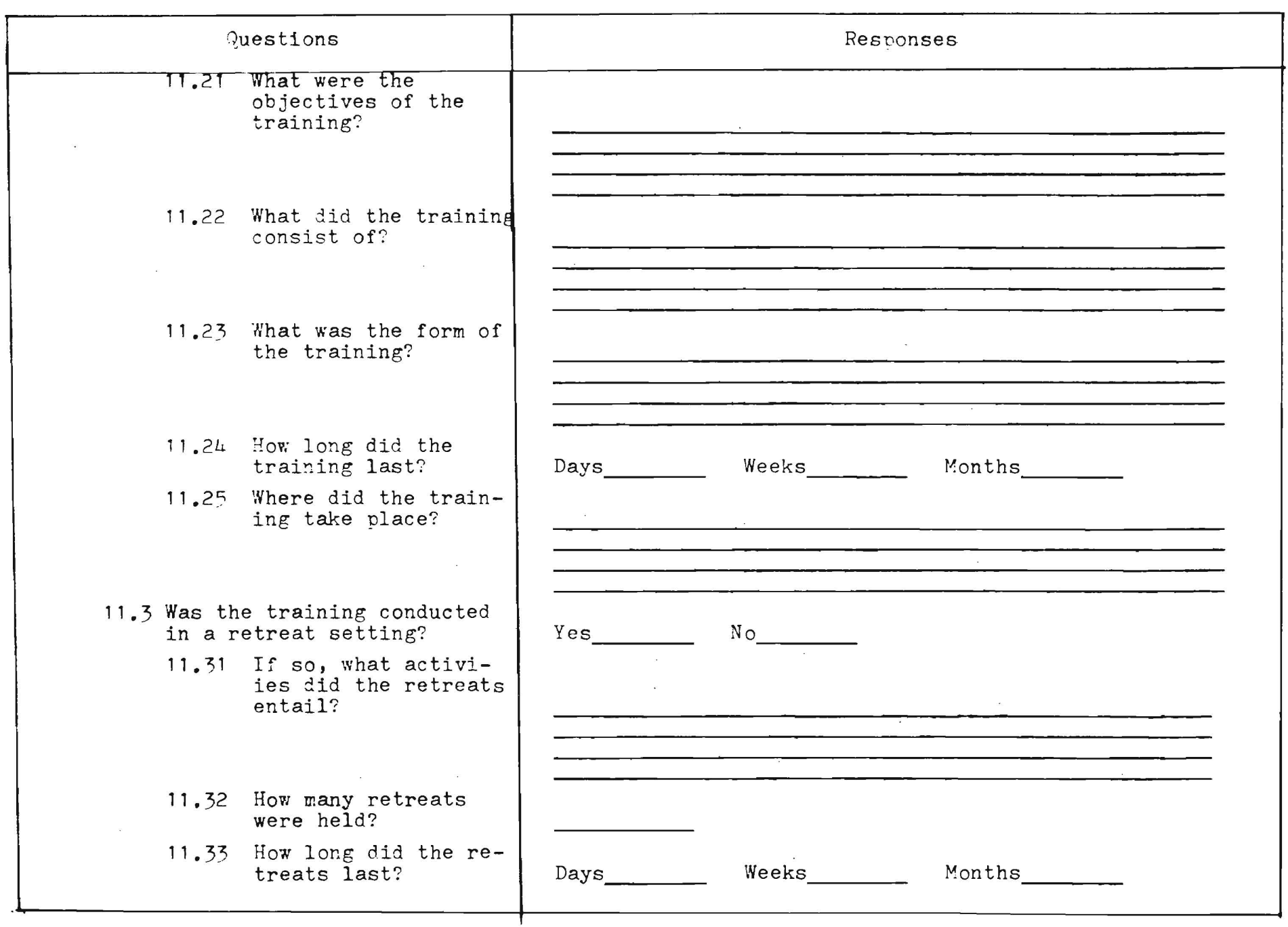




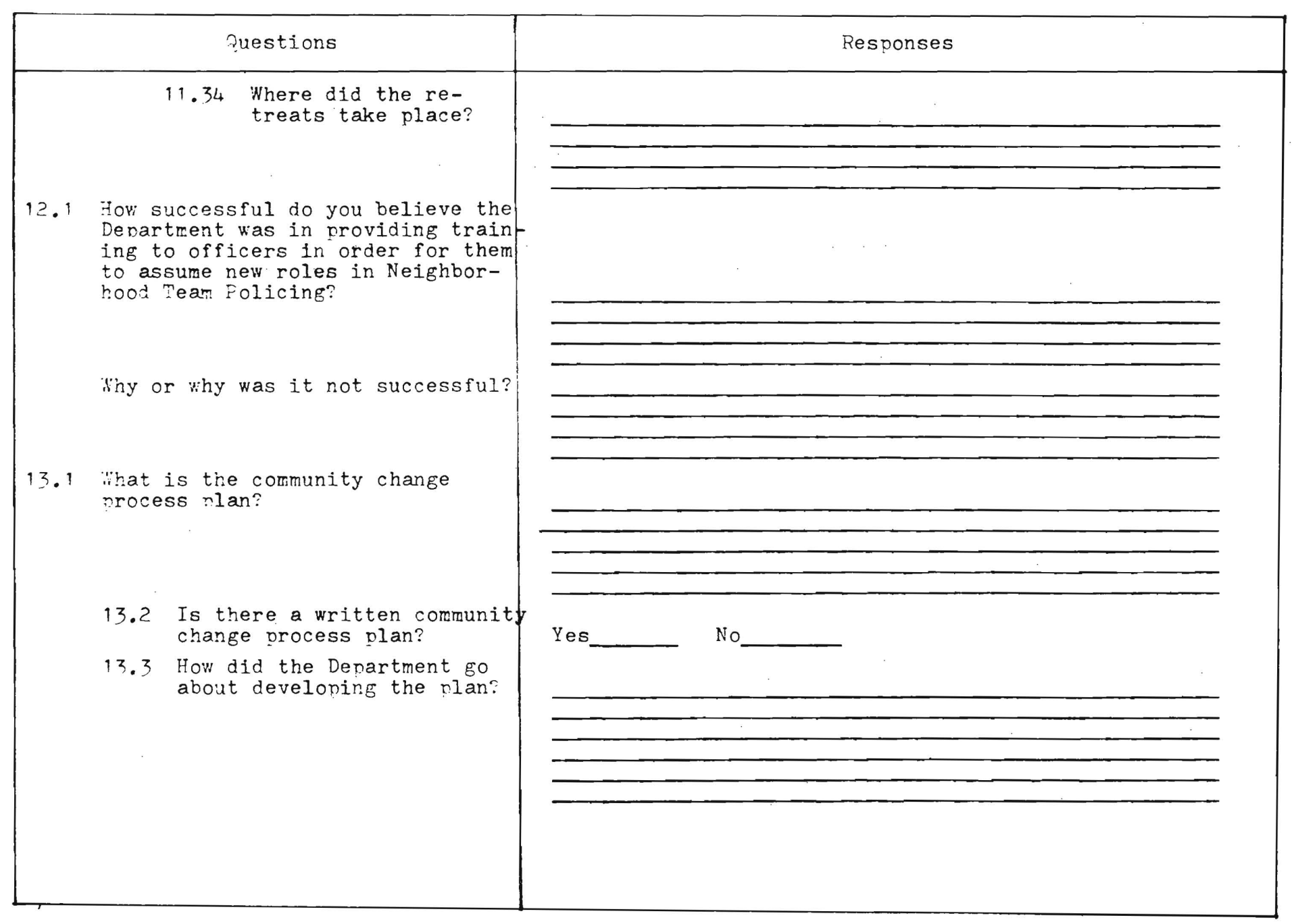




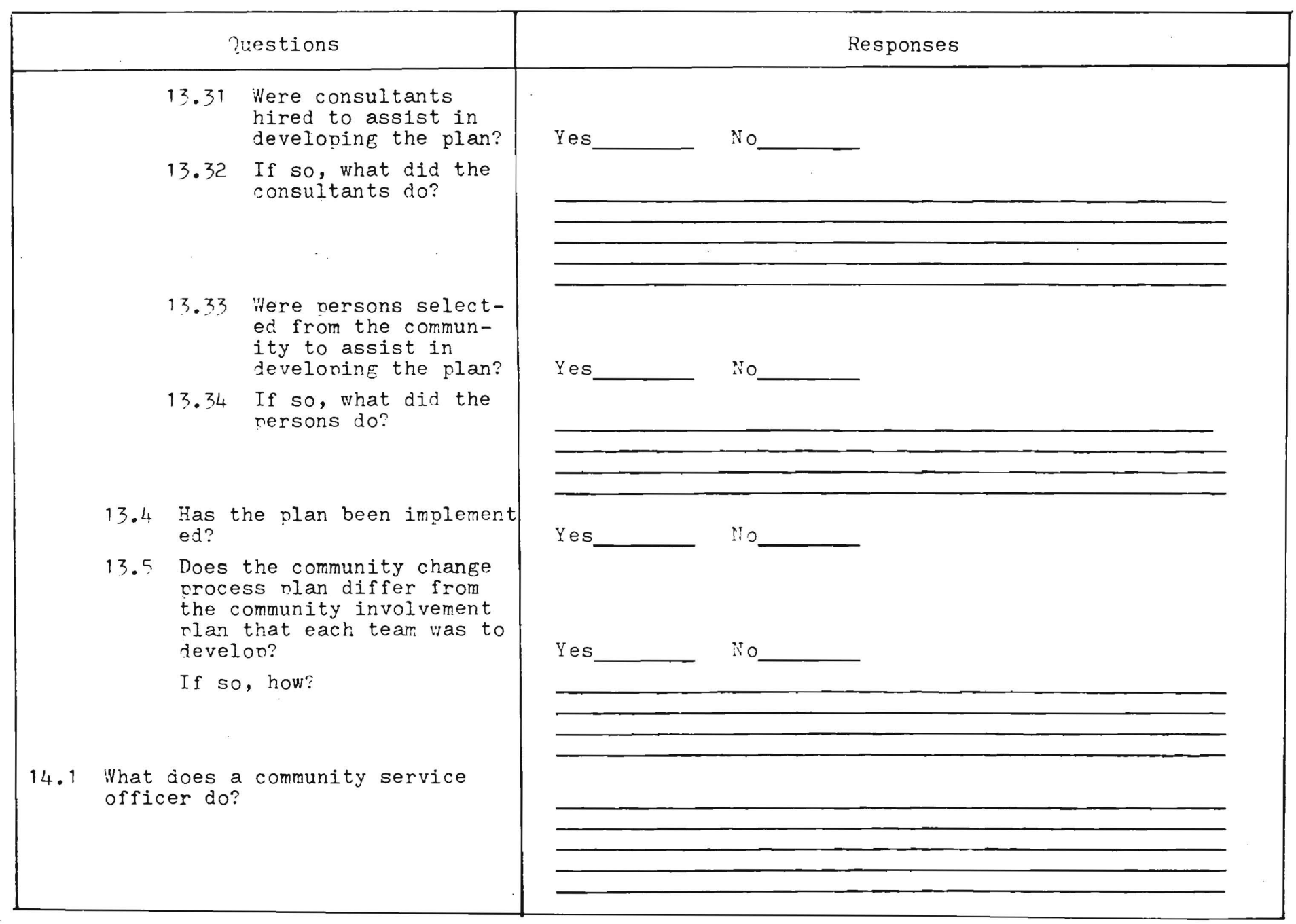




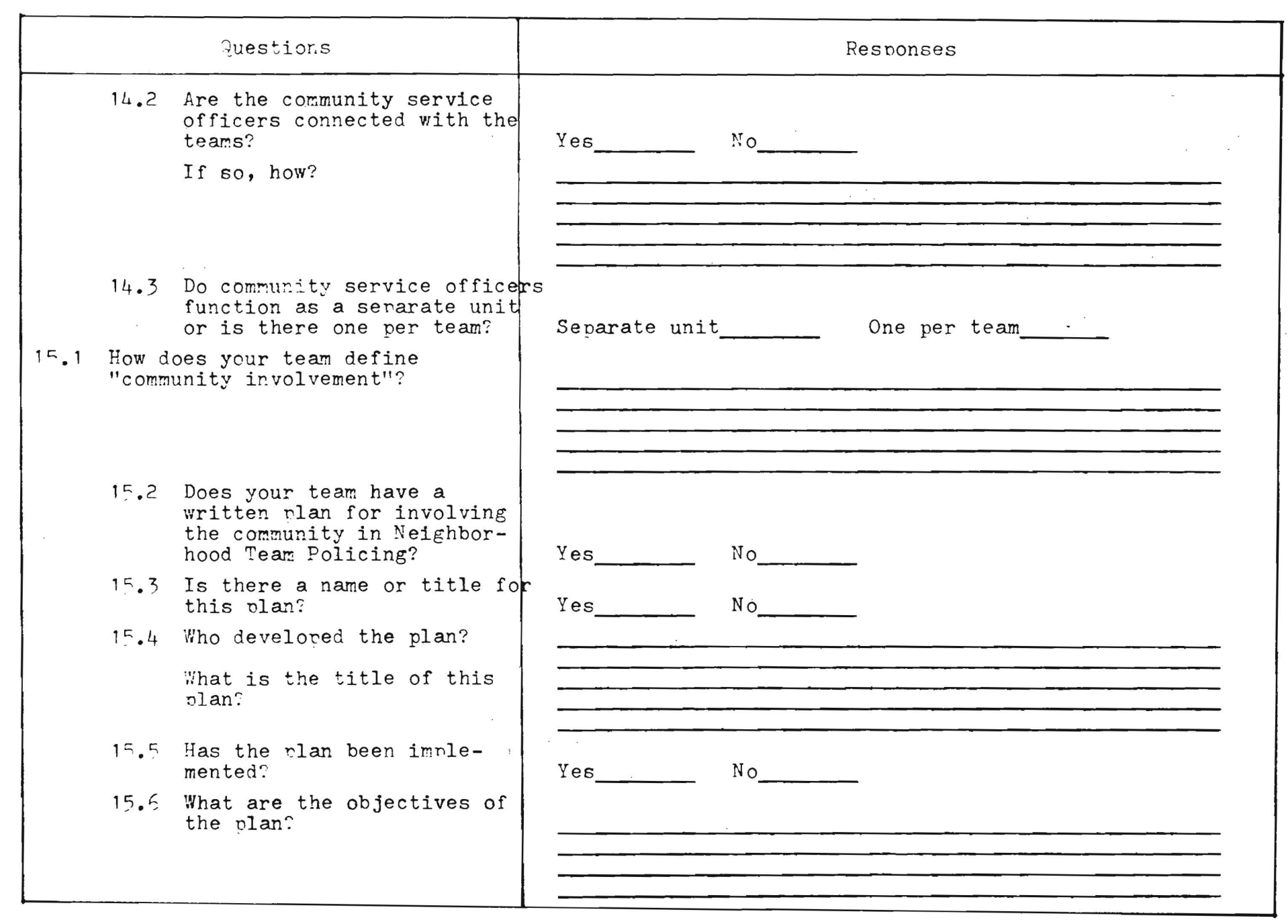




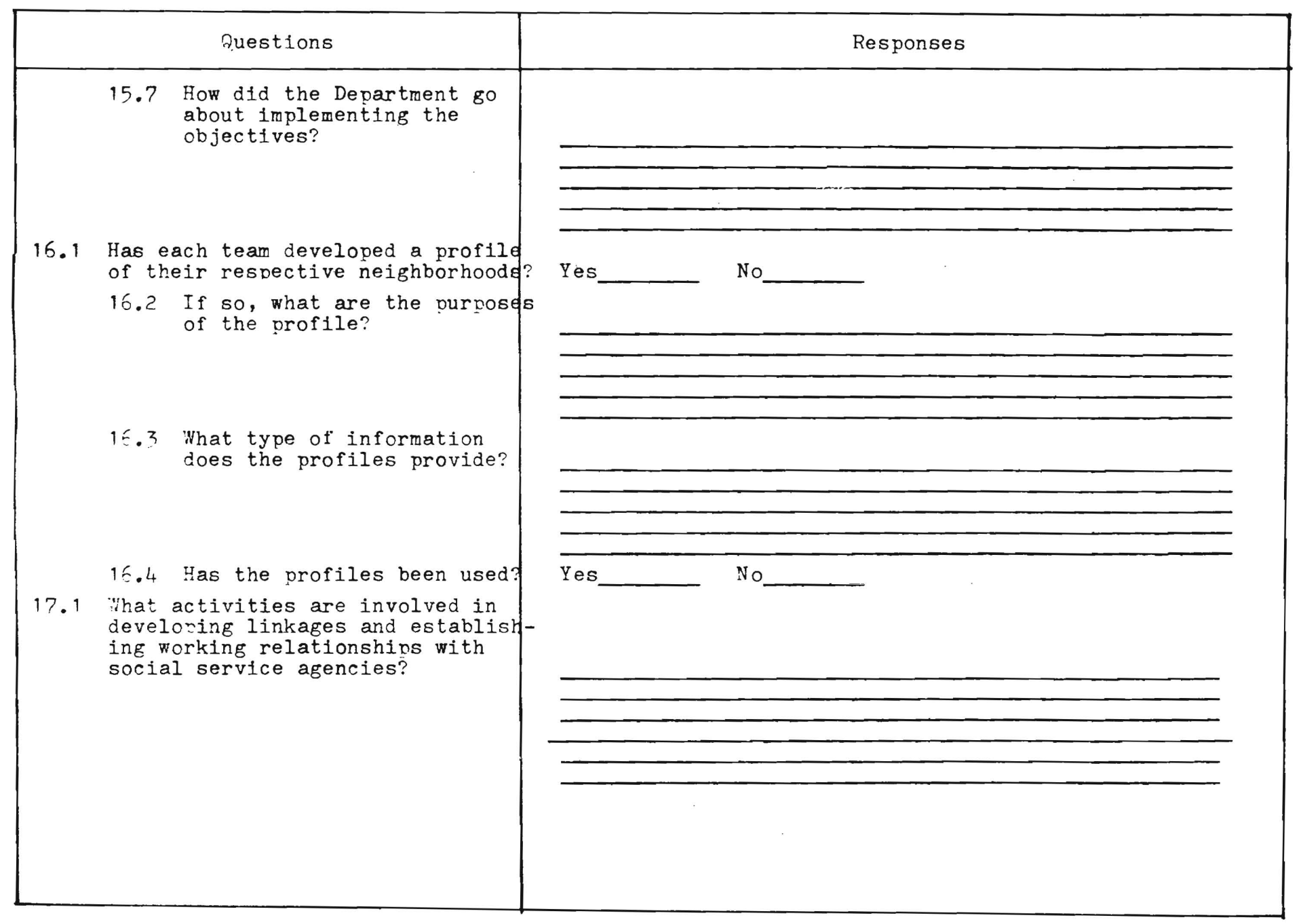

